\title{
Coastal oceanographic signatures of heat waves and extreme events of dense water formation during the period 2002-2012 (Barcelona, NW Mediterranean)
}

\author{
Jorge Guillén, Laura Arin, Jordi Salat, Pere Puig, Marta Estrada, Albert Palanques, \\ Gonzalo Simarro, Josep Pascual \\ Institut de Ciències del Mar, CSIC, Passeig Maritim de la Barceloneta, 37, 08003 Barcelona, Spain. \\ (JG) (Corresponding author) E-mail: jorge @icm.csic.es. ORCID iD: https://orcid.org/0000-0001-7162-8135 \\ (LA) E-mail: larin@icm.csic.es. ORCID iD: https://orcid.org/0000-0001-8800-5583 \\ (JS) E-mail: salat@icm.csic.es. ORCID iD: https://orcid.org/0000-0001-6139-5673 \\ (PP) E-mail: ppuig@icm.csic.es. ORCID iD: https://orcid.org/0000-0001-6189-5504 \\ (ME) E-mail: marta@icm.csic.es. ORCID iD: https://orcid.org/0000-0001-5769-9498 \\ (AP) E-mail: albertp@icm.csic.es. ORCID iD: https://orcid.org/0000-0003-2544-2342 \\ (GS) E-mail: simarro@icm.csic.es. ORCID iD: https://orcid.org/0000-0002-6420-5975 \\ (JP) E-mail: jpascual@ meteolestartit.cat. ORCID iD: https://orcid.org/0000-0002-7844-1741
}

\begin{abstract}
Summary: In a global context of climate change affecting the marine environment, it is important to consider the effect of extreme events in driving ecological change and to gain a better understanding of conditions to be expected under future scenarios. In this study we focus on monthly oceanographic data collected off Barcelona city during the period 2002-2012, in which extreme air temperatures and exceptional oceanographic events were reported in the western Mediterranean basin. These included two extreme heat waves and major episodes of dense water formation that produced unusually large deepwater contributions, induced oceanographic changes in the coastal zone and caused significant alterations to the marine ecosystem. To determine whether routine monitoring of oceanographic variables in a coastal zone can provide information for recognizing such large-scale events, temperature, salinity, turbidity and fluorescence were analysed to identify their signatures. The results provide an additional tool for monitoring oceanographic events and improving forecasts and future projections.
\end{abstract}

Keywords: coastal monitoring; decadal variability; water density; turbidity; fluorescence; extreme events.

Respuesta oceanográfica en la zona costera a olas de calor y eventos extremos de formación de agua densa ocurridos durante el período 2002-2012 (Barcelona, NO Mediterráneo)

Resumen: En un contexto global de cambio climático es importante considerar los efectos que producen los eventos extremos de escala regional sobre la ecología de las zonas costeras, para conseguir una mejor comprensión de las condiciones esperables en futuros escenarios. En este trabajo se aborda el estudio de una serie temporal de parámetros oceanográficos obtenida frente a la ciudad de Barcelona durante el período 2002-2012, cuando en el Mediterráneo occidental se identificaron episodios de temperaturas extremas y eventos oceanográficos poco habituales. Estos episodios incluyen dos olas de calor severas y episodios de formación de agua densa de especial intensidad que alcanzaron profundidades inusuales, indujeron a cambios oceanográficos en la zona costera y causaron alteraciones significativas del ecosistema marino a escala regional. La monitorización rutinaria de parámetros oceanográficos en la zona costera ha demostrado ser una herramienta valiosa para identificar estos eventos de gran escala y caracterizar su huella a partir de las medidas de temperatura, salinidad, turbidez y fluorescencia en la columna de agua. Los resultados obtenidos proporcionan una herramienta adicional para la monitorización de eventos oceanográficos y para mejorar su predicción.

Palabras clave: monitorización costera; variabilidad en décadas; densidad del agua; turbidez; fluorescencia; eventos extremos.

Citation/Como citar este artículo: Guillén J., Arin L., Salat J., Puig P., Estrada M., Palanques A., Simarro G., Pascual J. 2018. Coastal oceanographic signatures of heat waves and extreme events of dense water formation during the period 20022012 (Barcelona, NW Mediterranean). Sci. Mar. 82(4): 189-206. https://doi.org/10.3989/scimar.04766.26A

Editor: A. Alvera.

Received: February 14, 2018. Accepted: November 22, 2018. Published: December 10, 2018.

Copyright: ( 2018 CSIC. This is an open-access article distributed under the terms of the Creative Commons Attribution 4.0 International (CC BY 4.0) License. 


\section{INTRODUCTION}

Understanding marine environmental processes that operate simultaneously but have different time scales (ranging from turbulence to global changes) would require time series of oceanographic variables with high frequency and for long periods (decades) at many points. The combination of long-term highfrequency series and good spatial resolution cannot be applied to the entire marine environment, but repeated long-term monitoring of stations offers the opportunity of extrapolating the observations to larger areas. In addition, high-resolution satellite observations offer a necessary complement to marine observatories by enlarging the coverage of measurements. Numerical modelling is another additional tool for interpreting locally observed evidence in the framework of largerscale oceanographic processes. Long-term monitoring is required to calibrate remote observations and for data assimilation by predictive models. Time series of local observations should be integrated with numerical models to provide global and regional ocean-observing systems useful in the managing of marine regions (Carniel et al 2017). Several monitoring stations have been in operation along the western Mediterranean during the last few decades and attempts have been made to coordinate observations at national and international scales (CIESM 2008, Estrada et al. 2008, Tel et al. 2016). As an example, long-term monitoring of basic hydrological variables (temperature and salinity) in deep Mediterranean waters is coordinated in the HYDROCHANGES programme (CIESM 2002, Schroeder et al. 2013).

Time series of climatological and hydrological variables in the western Mediterranean have recorded exceptional events affecting both land and the ocean in the first decade of this century. For instance, air temperature was exceptionally high in Europe in the summer of 2003 (Luterbacher et al. 2004) and the whole period from September 2006 to February 2007 was identified as the warmest of the last half millennium in Europe (Luterbacher et al. 2007). The summer 2003 heat wave was considered extreme along the whole Mediterranean coast, with average temperatures from June to August $3.3^{\circ} \mathrm{C}$ above the $1900-2007$ mean (Castellà and Brunet 2011). The conditions during the heat wave were therefore used as indicative of a future climate change scenario to study its impact on the marine environment (Maynou et al. 2014). Seawater temperature variability influences living organisms in many ways. For example, changes in temperature have been related to zooplankton abundance (Fernández de Puelles and Molinero 2008) and to the sex ratio in fish even during their early development (Navarro-Martín et al. 2011). In shallow areas of the western Mediterranean, large-scale mass mortality events in benthic marine communities in summer 2003 were associated with positive long-lasting thermal anomalies in the seawater (Coma et al. 2009, Garrabou et al. 2009, Crisci et al. 2011), while changes in mortality and recruitment rates of sea grasses were also tentatively related to water temperature anomalies associated with the two heat waves (2003 and 2006) and to a general seawater warming (Marbà and Duarte 2010).

Time series recorded in western Mediterranean deep water also reported exceptional hydrographic changes related to the anomalously dry, cold and very windy winters of 2005 (López-Jurado et al. 2005, Salat et al. 2006, Font et al. 2007, Schroeder et al. 2008), 2006 (Marty and Chiavérini 2010, Palanques et al. 2012, Puig et al. 2013) and 2012 (Durrieu de Madron et al. 2013), during which large volumes of dense waters were generated by both deep open-sea convection and dense shelf water cascading. These anomalous years of dense water formation can have twofold effects. They can negatively affect fisheries, by producing temporary fishing collapses (Company et al. 2008, Martin et al. 2016) or can be beneficial to sessile deep-sea benthic communities by enhancing the trophic web (Orejas et al. 2009, Gori et al. 2013, Taviani et al. 2016).

Therefore, it appears that episodic and "exceptional" events that produce changes in thermohaline variables of western Mediterranean water masses have become relatively frequent during the past few years. From this perspective, we study the contribution of these exceptional events to coastal zone oceanographic variability and investigate whether coastal time series observations could be used to recognize or predict these events. In this study, we use monthly surveys carried out from 2002 to 2012 to examine the evolution of temperature, salinity, suspended sediment concentration and chlorophyll $a$ in the water column of coastal waters in front of Barcelona city to analyse the seasonal and interannual variability of these variables, and to identify and characterize traces of the exceptional events that occurred during the study period.

\section{Oceanographic setting and study area}

The general characteristics of the water masses and their circulation in the western Mediterranean have been well described in previous works (e.g. Font et al. 1988). Low-salinity Atlantic Waters (AW) inflows at surface through the Strait of Gibraltar following a cyclonic path in the western Mediterranean. These recently arrived AW (rAW) reaches the Balearic Islands and the Strait of Sicily in a few months. Then, it flows towards the north to the Tyrrhenian and Ligurian seas, reaching the northern slope, and continues towards the south, affecting the Catalano-Balearic Sea and closing a cyclonic circuit in the NW Mediterranean basin (Millot 1990). The AW becomes progressively modified along this pathway under the effect of vertical mixing and evaporation processes that act mainly during the winter season. In addition, along the northern slope, AW incorporates freshwater inputs from rivers that help to maintain lower salinity inshore, but further offshore it becomes saltier as it remains in the central open-sea part of the Catalano-Balearic Sea. This old AWs (oAW) is separated from the coastal rAW by a marked shelf-slope density front (Salat and Font 1987, Font et al. 1988).

Along the shelf and slope and in the open sea of the northwestern Mediterranean, wintertime heat loss, 
Table 1. - Acronyms and characteristic hydrographic variables of water masses in the northwestern Mediterranean (modified from Salat et al. 2006) $\left(\theta\right.$, temperature; Sp, salinity; $\sigma_{\theta}$, density anomaly).

\begin{tabular}{lccc}
\hline Acronym & $\theta\left({ }^{\circ} \mathrm{C}\right)$ & $\mathrm{Sp}$ & $\sigma_{\theta}\left(\mathrm{kg} \mathrm{m}^{-3}\right)$ \\
\hline rAW & $>13$ & $<37.5$ & $<28.1$ \\
oAW & $>13$ & $37.9-38.2$ & $<28.9$ \\
WIW & $12.6-13.0$ & $38.1-38.3$ & $28.9-29.0$ \\
LIW & $13.0-13.4$ & $38.48-38.55$ & 29.075 \\
WMDW & $12.72-12-90$ & $38.43-38.50$ & $29.115-29.145$ \\
\hline
\end{tabular}

vertical convection and mixing typically affects the upper layer occupied by oAW, forming an intermediate layer characterized by a relative minimum temperature (Lacombe and Tchernia 1972, Salat and Font 1987) and currently known as Western Mediterranean Intermediate Water (WIW). These waters typically spread towards the SW, and their signature just below the AW is progressively eroded in summer and autumn. Levantine Intermediate Water (LIW), which originates in the Levantine basin, in the eastern Mediterranean, flows into the northwestern Mediterranean below the WIW, also following a cyclonic path in the western Mediterranean. LIW usually has both temperature and salinity maxima centred around 400-600 m depth (Font 1987, Millot 2013). Deeper, the water column is occupied by Western Mediterranean Deep Water (WMDW), which can be identified by relative minima of both potential temperature and salinity (Table 1 ).

The dynamics of the NW Mediterranean Sea is driven by the seasonal cycle. As noted above, the water masses are modified in the course of the year by the ocean/atmosphere interaction. Surface temperature varies seasonally by more than $14^{\circ} \mathrm{C}$ (Salat et al. 2002). A seasonal thermocline develops from early spring to late autumn, whereas in winter the water column homogenizes down to different depths, depending on wind strength, air temperature, surface salinity and marine circulation. In the northwestern Mediterranean open-sea winter heat losses and evaporation caused by cold, dry northerly wind episodes cause a completely homogeneous water column down to the bottom. This is a well-known region for open-sea deep convection (MEDOC Group 1970), which produces new deep water (WMDW) that can occur on a yearly basis (Somot et al. 2016). On the continental shelf of the Gulf of Lions, these winds can also induce the cooling and evaporation of coastal waters, which are initially less saline but become colder and denser, sinking and travelling over the bottom of the shelf and cascading down the continental slope, mainly through submarine canyons, until they reach their equilibrium depth (Millot 1990, Durrieu de Madron et al. 2005). In the initial stages of the cascading process, dense waters spread around the shelf break depth (150-200 m) and contribute to the formation of WIW (Fieux 1974, Dufau-Julliand et al. 2004). In extremely cold and dry winters, dense shelf waters can cascade to deeper levels, sometimes mixing with the waters present, namely the warmer and saltier LIW layer and the underlying WMDW (Salat et al. 2006, Font et al. 2007, Puig et al. 2013) to reach the bottom, and also contributing to the renewal of the WMDW.

Salat et al. (2002) reported on the way in which the seasonality of the water column stratification and the riverine inputs affect the hydrographic structure and the distribution of nutrients, chlorophyll and suspended matter on the Ebro shelf (NW Mediterranean). These seasonal cycles should be superimposed on long-term decadal trends such as the progressive increase in temperature and salinity that has been detected in surface waters of the western Mediterranean during the past few decades (Krahmann and Schott 1998, Salat and Pascual 2002, 2006, Vargas-Yáñez et al. 2005). The initial trends reported by Vargas-Yáñez et al. (2008) for the first half of the 20th century accelerated after the mid-century (Rholing and Bryden 1992, Tsimplis and Baker 2000). An overall warming trend of around $+0.02^{\circ} \mathrm{C}$ to $0.03^{\circ} \mathrm{C} \mathrm{yr}^{-1}$ recorded in coastal areas for the period 1974-2005 showed a sharp reduction in the warming rates during the 1990s, suggesting that Mediterranean warming is superimposed on decadal oscillations (Vargas-Yáñez et al. 2008).

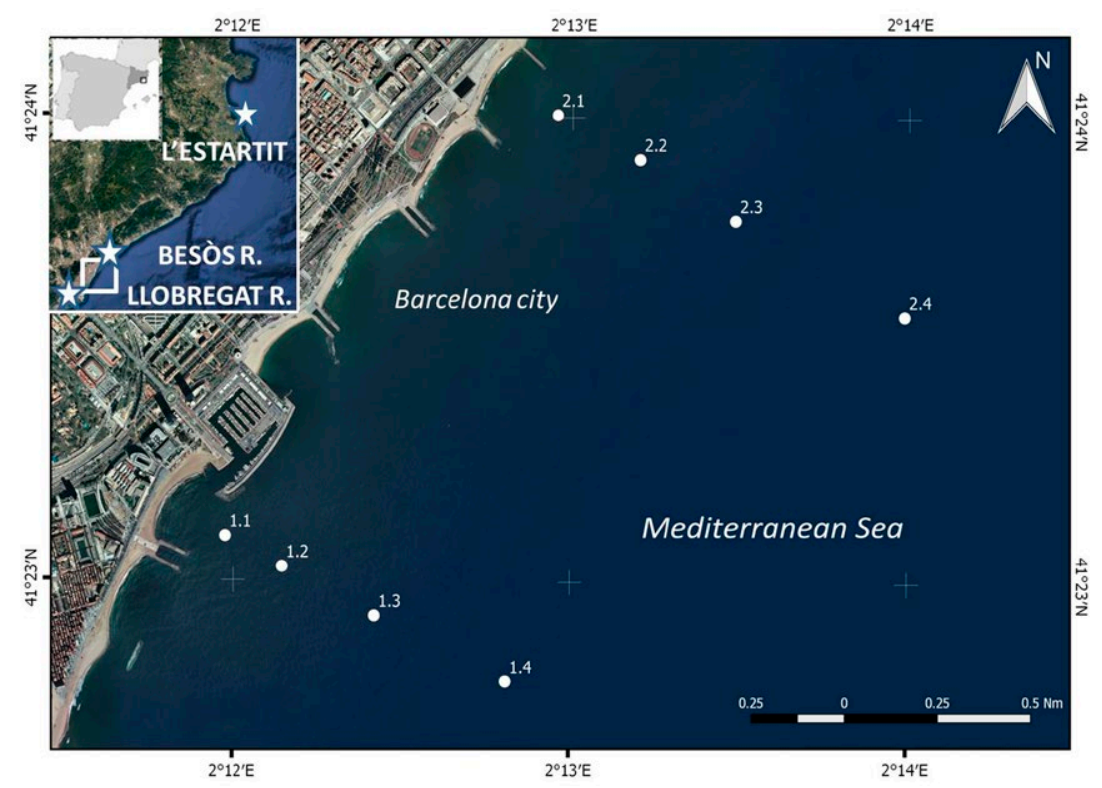

Fig. 1. - Study area and sampling stations (graphical scale in nautical miles). 
The city of Barcelona (ca. 2 million inhabitants plus an increasing tourist population reaching an average of several million visits per year) is located in the northwestern Mediterranean, on the Catalan coast (Fig. 1). It is a micro-tidal zone with a typical range of about $0.2 \mathrm{~m}$, in which waves are the main stirring mechanism controlling coastline evolution (Ojeda and Guillén 2008). The most energetic storms approach from the east, have a typical duration of a few days, and are often associated with meteorological cyclonic activity in the western Mediterranean (Ojeda and Guillén 2008). The city is flanked by two small rivers, the Besòs in the north and the Llobregat in the south, and several storm sewers discharge freshwater to the coastal area during rainfall periods (Fig. 1). An important commercial harbour is located on the left side of the Llobregat River mouth. To the north, along the city seafront there are three marinas and more than $3 \mathrm{~km}$ of beaches before the Besòs River mouth is reached.

The hydrography of Barcelona coastal waters is characterized by strong seasonality, with obvious major anthropogenic influences (Romero et al. 2014). However, seasonal variability also includes natural variability of inorganic nutrients and phytoplankton. In general, observed nutrient concentrations are highest in winter and lowest in summer (Arin et al. 2013), since the main mechanisms of fertilization of the coastal water masses are linked to both the disruption of the thermocline and the occurrence of freshwater inputs, associated either with the rivers or with the storm sewers. Phytoplankton biomass shows a main peak in winter/early spring and often a secondary peak in autumn (Arin et al. 2013). Interannual changes in phytoplankton composition related to nutrient inputs associated with oceanic water intrusions have been reported (Arin et al. 2013).

\section{MATERIALS AND METHODS}

\section{Sampling and data}

The present work is based on the time series of oceanographic data routinely collected off Barcelona city as part of the activities of the Coastal Ocean Observatory (COO) of the Institute of Marine Sciences (ICM-CSIC) of Barcelona. The COO was created in 2001 to analyse land-sea interactions under the perspective of the impact of large cities on the marine environment, providing complementary information to existing monitoring programmes. The $\mathrm{COO}$ aims to conduct physical, morphological and biological monitoring with the highest feasible resolution and a longterm perspective in order to determine the behaviour and evolution of a coastal system where natural and human influences coexist.

The data used in this study were obtained from 117 monthly hydrographic surveys carried out between April 2002 and November 2012, with a mean periodicity of 33 days (maximum 94 days, minimum 11 days). The surveys were carried out using the small boat Itxasbide, which is $7.6 \mathrm{~m}$ long. Each survey consisted of eight CTD casts using an SBE 25 CTD coupled with turbidity and fluorescence sensors. Casts were distributed along two transects $2.5 \mathrm{~km}$ apart across the inner continental shelf. Each transect comprised four stations at water depths of 10,20,30 and $40 \mathrm{~m}$ water depth (hereafter, respectively, stations 1-1, 1-2, 1-3 and 1-4 for transect 1 and 2-1, 2-2, 2-3 and 2-4 for transect 2) (Fig. 1). Surface and bottom samples for laboratory measurements of salinity, turbidity and chlorophyll $a$ were taken with a bucket (between 0 and $0.5 \mathrm{~m}$ depth) and with a Niskin bottle (1.5 $\mathrm{m}$ above the bottom), respectively.

CTD raw data were processed with the SBE data processing software (SEASOFT - Win32) to obtain the hydrographical variables of the water column (conductivity, temperature and depth) every $0.5 \mathrm{~m}$. TEOS10 hydrographic variables (temperature, salinity and density) were calculated following the Gibbs Seawater Oceanographic Toolbox (IOC et al. 2010). Time was set to GMT.

During the study period, two different SBE 25 CTD probes were used (SN 97 and 104). The SN 97 CTD, used from April 2002 to August 2007, was calibrated in February 2002, May 2003 and February 2005. The SN 104 CTD, used thereafter, was calibrated in March 2002, August 2007 and August 2008. The salinity of water samples for routine CTD data control was analysed using a Guildline Autosal 8400B laboratory salinometer. Discrepancies in salinity measurements were small (mean difference, 0.08; relationship, $\mathrm{Y}=0.998 \mathrm{X}$; $\mathrm{N}=605$ samples; $\mathrm{R}^{2}=0.99$ ).

Turbidity was measured by a $25-\mathrm{cm}$ Sea Tech transmissometer (SN 418) (based on light attenuation) during the first 23 surveys, and two Seapoint turbidimeters (SN 10250 and 102666) (based on light scattering) thereafter. Water samples were filtered through polycarbonate filters to determine suspended particulate matter concentration $\left(\mathrm{mg} \mathrm{L}^{-1}\right)$. The turbidity measurements were calibrated against the suspended sediment concentration (SSC) by means of a linear regression. A specific calibration was performed for each sensorCTD set $\left(\mathrm{N}=430 ; \mathrm{R}^{2}=0.55,0.72,0.69 ; 0.16\right.$ for the different calibrations).

Fluorescence was measured by Sea Tech Fluorometers (Seapoint Chlorophyll Fluorometers) SN 228 and 2205, and a WETLabs WETStar Fluorometer (SN 2089). The fluorescence measurements from the bottom water samples were correlated against chlorophyll $a$ concentrations (as an indicator of phytoplankton biomass). Data from surface waters ( $<0.5 \mathrm{~m}$ water depth) were discarded due to a possible phytoplankton photoinhibition (light induced decrease in fluorescence) that biases the chlorophyll $a$-fluorescence correlation (Estrada 1996). For chlorophyll $a$ analysis, water samples $(100 \mathrm{~mL})$ were filtered through Whatman GF/F fibre filters, which were then kept frozen. Chlorophyll $a$ was extracted in $90 \%$ acetone for approximately $24 \mathrm{~h}$ in the dark and at $4^{\circ} \mathrm{C}$, and the fluorescence of the extract was measured with a Turner Designs fluorometer (Yentsch and Menzel 1963). Five linear regressions between fluorescence and chlorophyll $a$ were established according to the different fluorescence sensors and CTD configurations (total number of samples, 
$773 ; \mathrm{N}=48$ to $345 ; \mathrm{R}^{2}=0.41,0.55,0.55,0.64$ and 0.81 ). The resulting expressions were used to calibrate the fluorescence data as $\mu \mathrm{g} \mathrm{L}^{-1}$ of chlorophyll $a$.

Several pluvial outflows discharge in the coastal area of Barcelona city during rainfall periods and, before analysing the results, we were not confident about the similarity between the two hydrographic transects. However, data obtained in transects 1 and 2 were very similar. For example, the comparison between the mean values of variables obtained from the deepest CTD profiles (stations 1.4 and 2.4) revealed highly correlated temperature, salinity, density and SSC $\left(\mathrm{R}^{2}>0.97\right)$ during the whole study period. Therefore, to illustrate the oceanographic conditions found and to avoid reiteration, only data obtained in transect 1 are shown in this paper.

Within the study period, during summer 2009 and from February to May 2011, we had the opportunity to investigate the short-term variability of surface water temperature through a temperature sensor integrated in an AQUAlogger 210TYT probe moored at the position of the CTD at station 1.1 (Fig. 1), where a harbour approach navigation post light is located. Measurements were obtained every 30 minutes in subsurface waters (1.5 $\mathrm{m}$ below surface water level).

Monthly meteorological information (mean air temperature and accumulated rainfall) and wave climate (accumulated hours of storm waves) in Barcelona during the study period were provided by the Observatori Fabra (http://www.fabra.cat/meteo/) and Puertos del Estado (http://www.puertos.es/es-es/oceanografia/), respectively.

\section{Diel variability of temperature and potential bias of CTD measurements}

Detailed seawater temperature observations in spring 2011 measured at the harbour approach navigation post light (station 1.1) revealed a strong diel variability in shallow waters (Fig. 2). The diel temperature variation associated with the cycle of solar heating was about $0.5^{\circ} \mathrm{C}$ to $1^{\circ} \mathrm{C}$ in surface waters $(1.5 \mathrm{~m}$ below the surface). The maximum diel temperature variation reached almost $2^{\circ} \mathrm{C}$. The coldest water typically occurred in the early morning, not later than 7:00 $\mathrm{h}$, and the warmest in late afternoon, around 17:00-18:00 h. Diel temperature variability was lower at $10 \mathrm{~m}$ water depth (usually lower than $0.5^{\circ} \mathrm{C}$ ) and showed a similar pattern (data not shown). Seasonal temperature variations such as the strong increasing gradients in spring were superposed on diel oscillations. For instance, the surface temperature increased at an average rate of $0.09^{\circ} \mathrm{C} \mathrm{day}^{-1}$ from March to June 2011 (Fig. 2). Strong winds and wave storm events can also induce temperature changes, such as the one occurring in late May 2011, which mask the diel cycle caused by solar heating.

High-frequency temperature data were also used to assess possible biases in the routine sampling, since CTD measurements were always carried out between 8:00 and 13:00 h. According to the observed diel cycles in spring and summer, the measured water temperatures could be expected to be (on average) slightly

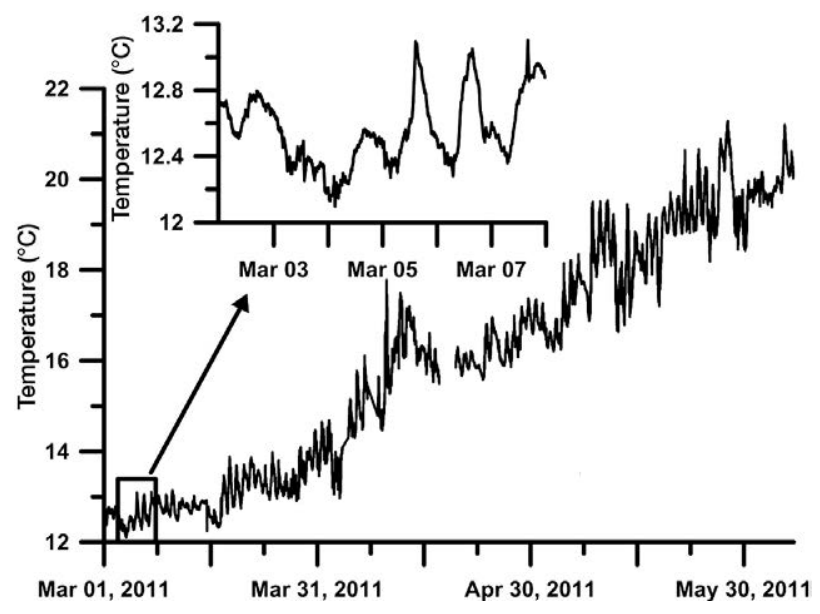

Fig. 2. - Short-term temperature variability at $1.5 \mathrm{~m}$ water depth (station 1.1).

colder than the mean daily temperature, at least during these seasons. Consequently, the representativeness of the monthly data used in this work can only be considered within the perspective of a long-term series, in which mean monthly values can be derived from a single measurement.

\section{RESULTS}

This section is devoted to a description of space and time variability of the data collected during the period 2002-2012. The first sub-section analyses the seasonal and interannual variability of the main external drivers that modify oceanographic conditions in coastal waters: air temperature, rainfall and wave height. In the next sub-sections, the results of first seasonal scales and then interannual scales are presented. The analysis includes vertical and across-shelf distributions of these variables.

\section{Air temperature, rainfall and wave height}

The monthly air temperature ranged between $6^{\circ} \mathrm{C}$ and $28^{\circ} \mathrm{C}$. The warmest months were August 2003 and July 2006, and the highest annual mean was recorded in 2006. The coldest months were February and December 2005 and January 2010, and the lowest annual mean was in 2010. The mean annual cycle shows that the warmest period was June-August and the coldest December-February (Fig. 3).

The annual rainfall ranged between 450 and 950 $\mathrm{mm}$. It was above $700 \mathrm{~mm}$ in 2002, 2010 and 2011 and below $600 \mathrm{~mm}$ in the remaining years. The mean monthly rainfall during the study period ranged between 31 and $101 \mathrm{~mm}$. The driest period within the mean annual cycle was from June to August and the maximum mean rainfall occurred in October (Fig. 3).

Storm waves also displayed strong seasonality, as illustrated by the accumulated hours of significant wave height (Hs) higher than $2 \mathrm{~m}$ (Fig. 3), which is representative of the major storms for this area (Ojeda and Guillén 2008). Most of the storms occurred during the period from October to April, which is characterized by more than 10 hours per month of high-wave ac- 

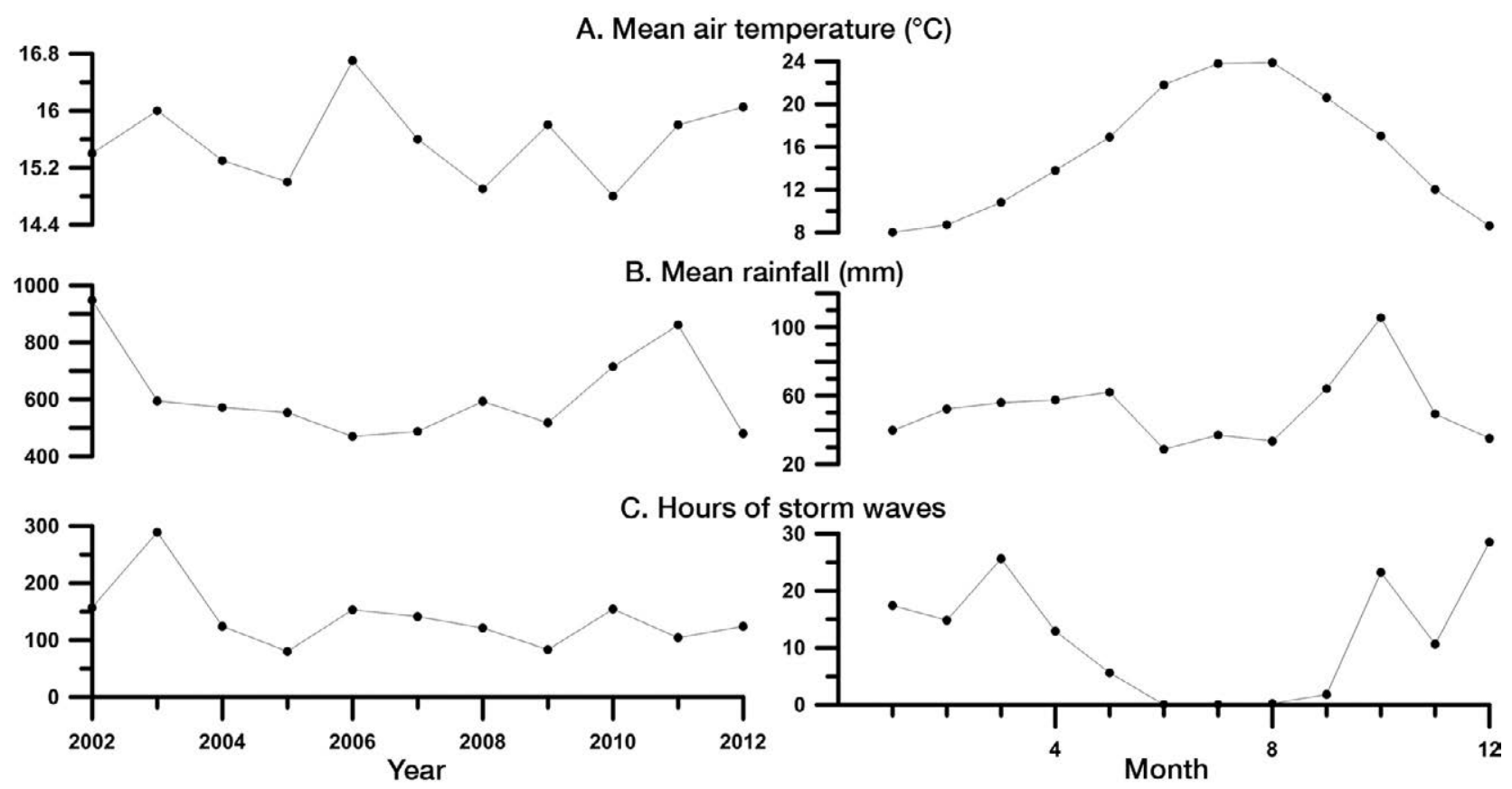

Fig. 3. - Interannual (left) and seasonal (right) distribution of A, air temperature $\left({ }^{\circ} \mathrm{C}\right)$, B, rainfall $(\mathrm{mm})$ and $\mathrm{C}$, waves (hours of storm waves).

Table 2. - Across-shelf variations of the measured variables, depth-averaged, in profiles at 10, 20, 30 and $40 \mathrm{~m}$ water depth $(1.1,1.2,1.3$ and 1.4 , respectively). In parenthesis mean values within the upper $10 \mathrm{~m}$ of the water column at each station.

\begin{tabular}{lcccc}
\hline \multicolumn{1}{c}{ Variable/depth } & 1.1 & 1.2 & 1.3 & 1.4 \\
\hline Temperature $\left({ }^{\circ} \mathrm{C}\right)$ & 17.77 & $17.37(17.69)$ & $17.01(17.72)$ & $16.71(17.71)$ \\
Salinity & 38.12 & $38.16(38.126)$ & $38.18(38.128)$ & $38.20(38.13)$ \\
Density $\left(\mathrm{kg} \mathrm{m}^{-3}\right)$ & 27.51 & $27.67(27.53)$ & $27.80(27.52)$ & $27.92(27.53)$ \\
SSC $\left(\mathrm{mg} \mathrm{L}^{-1}\right)$ & 1.24 & $1.15(0.98)$ & $0.97(0.89)$ & $0.92(0.83)$ \\
Chlorophyll $a\left(\mu \mathrm{g} \mathrm{L}^{-1}\right)$ & 1.08 & $1.06(1.05)$ & $0.98(0.92)$ & $0.89(0.82)$ \\
\hline
\end{tabular}

tivity. The period from May to September was hardly affected by high waves. The total annual time of storm waves ranged between 80 and 289 hours/year in 2005 and 2003, respectively (Fig. 3).

No interannual trends in air temperature, rainfall and waves were observed during the period 2002-2012 (Fig. 3).

\section{Spatial and seasonal variability}

\section{Across-shelf variability}

Across-shelf gradients of each variable are described using the average vertical values obtained at each station (Table 2). The depth-averaged temperature, SSC and chlorophyll $a$ values decreased progressively offshore, while salinity and density values increased. However, when only the shallowest $10 \mathrm{~m}$ of the water column at each station was considered (the full profile at station 1.1), an offshore decreasing trend of SSC and chlorophyll $a$ was detected, but temperature, salinity and density values remained constant across-shelf (Table 2). Therefore, acrossshelf gradients are a consequence of the different characteristics of deeper waters (less turbid, colder and saltier), whereas the shallow water layer $(0-10 \mathrm{~m})$ remains homogeneous across the inner shelf (Table 2 ). These averaged across-shelf gradients have strong seasonality, as shown in Figure 4. Gradients reached the maximum value during the summer period and almost disappeared in winter, when water masses became homogeneous across the shelf.

\section{Temperature}

Time series of seawater temperatures show the dominance of seasonal variability, with temperature increasing in spring and decreasing, more abruptly, in late autumn (Figs 5 and 6). The annual distribution of the monthly mean temperature at different levels, estimated from all surveys (Fig. 4), shows (i) rapid increases in temperature starting in April, (ii) higher temperatures from June to October (the warmest water at surface in August and between 20 and $40 \mathrm{~m}$ depth in September), (iii) cooling starting in October, and (iv) the lowest temperatures from December to March (minima in February or March).

The vertical distribution of the mean monthly temperatures displayed a decreasing trend from surface to bottom (Figs 5 and 7). The depth-averaged temperature at the deepest station $\left(40 \mathrm{~m}\right.$ water depth) was $16.71^{\circ} \mathrm{C}$ (range from $11.72^{\circ} \mathrm{C}$ to $22.83^{\circ} \mathrm{C}$ ), with extreme instantaneous measured values of $11.38^{\circ} \mathrm{C}$ and $26.21^{\circ} \mathrm{C}$. The stratification in temperature can be expressed with the standard deviation ( $\mathrm{sd}$ ) of this variable, whose maximum value $\left(\mathrm{sd}>2^{\circ} \mathrm{C}\right)$ was reached during the summer 

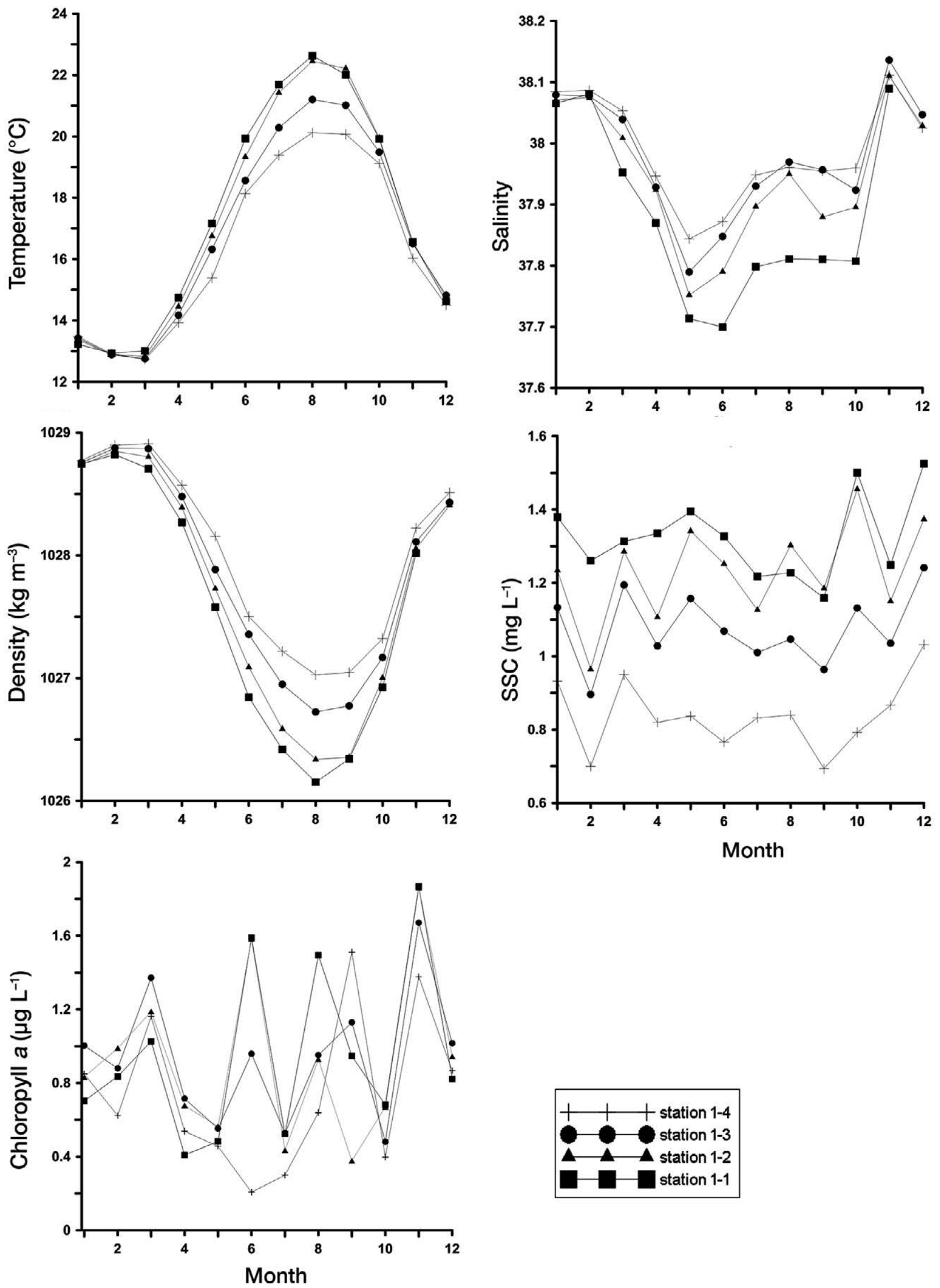

Fig. 4. - Annual distribution of monthly vertical average measured variables at stations 1.1, 1.2, 1.3 and 1.4. Across-shelf gradients tend to vanish during winter, except for suspended sediment concentration, which is higher in shallower waters. 
196 - J. Guillén et al.
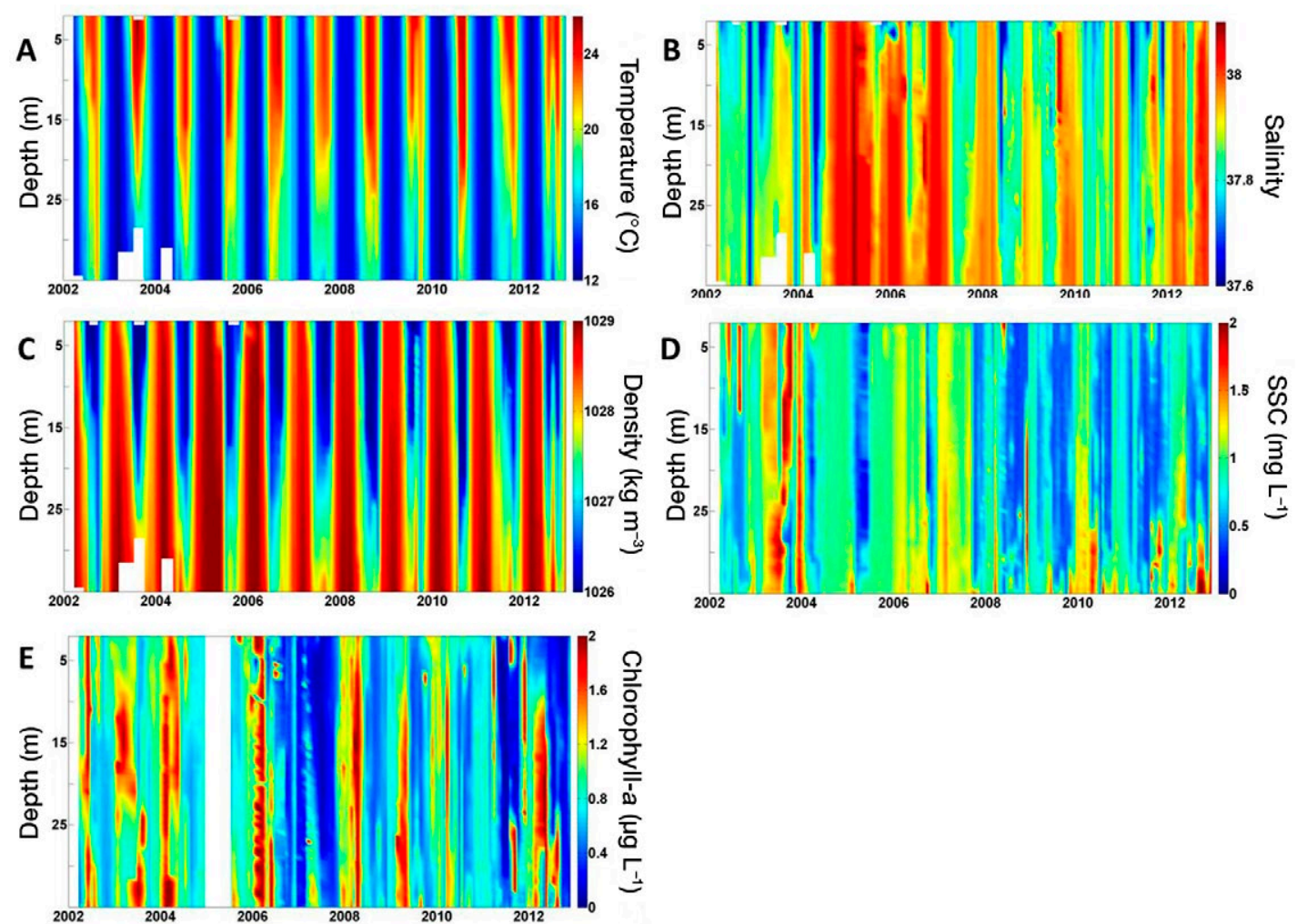

Fig. 5. - Time series of measured variables at station 1.4. A, temperature $\left({ }^{\circ} \mathrm{C}\right)$; B, salinity; C, density $\left(\mathrm{kg} \mathrm{m}^{-3}\right)$; $\mathrm{D}$, suspended sediment concentration $\left(\mathrm{mg} \mathrm{L}^{-1}\right)$; E, chlorophyll $a\left(\mu \mathrm{g} \mathrm{L}^{-1}\right)$.
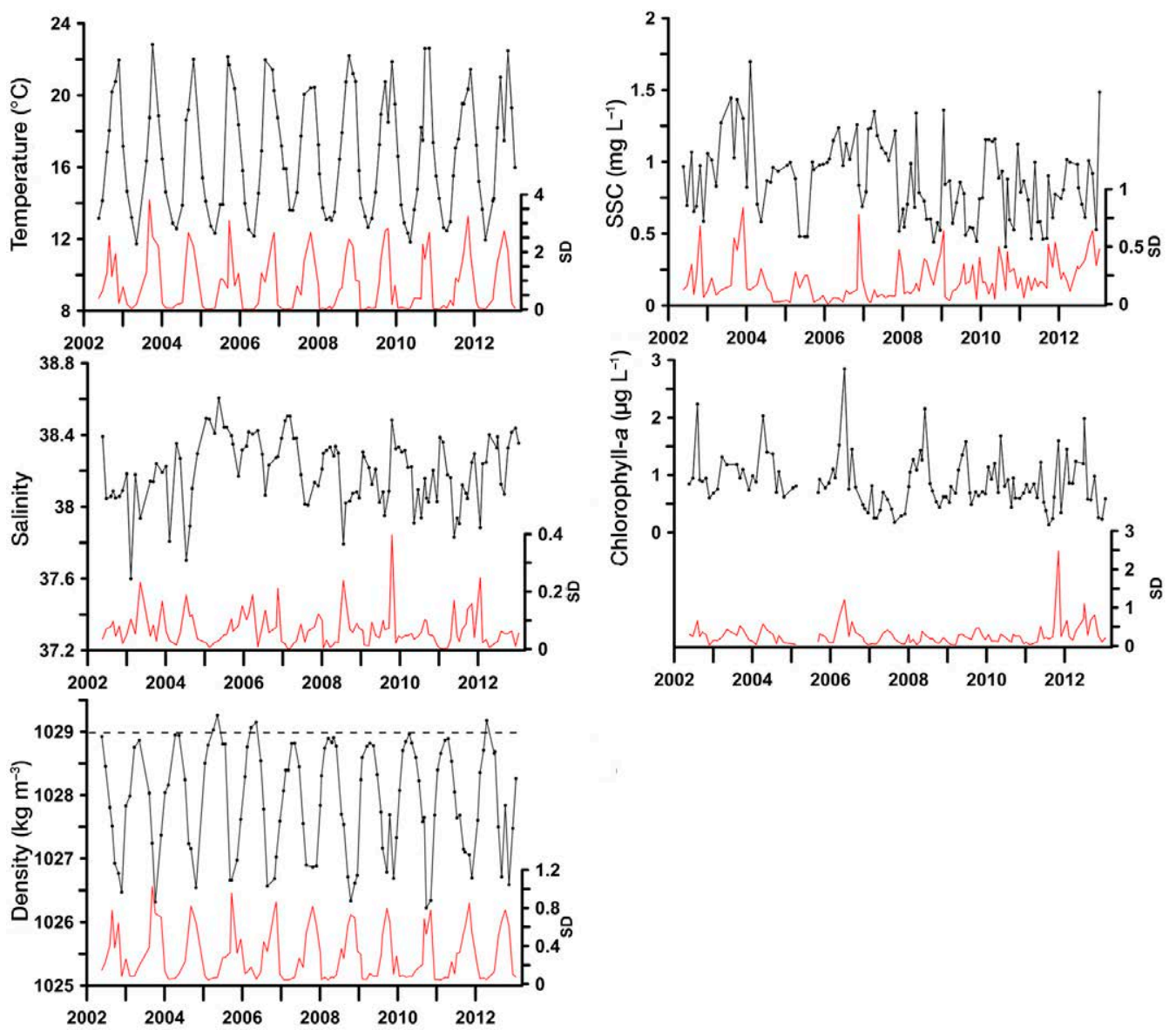

Fig. 6. - Time series of variables measured at station 1.4 (averaged values over $40 \mathrm{~m}$ of water column) and standard deviation (sd). 

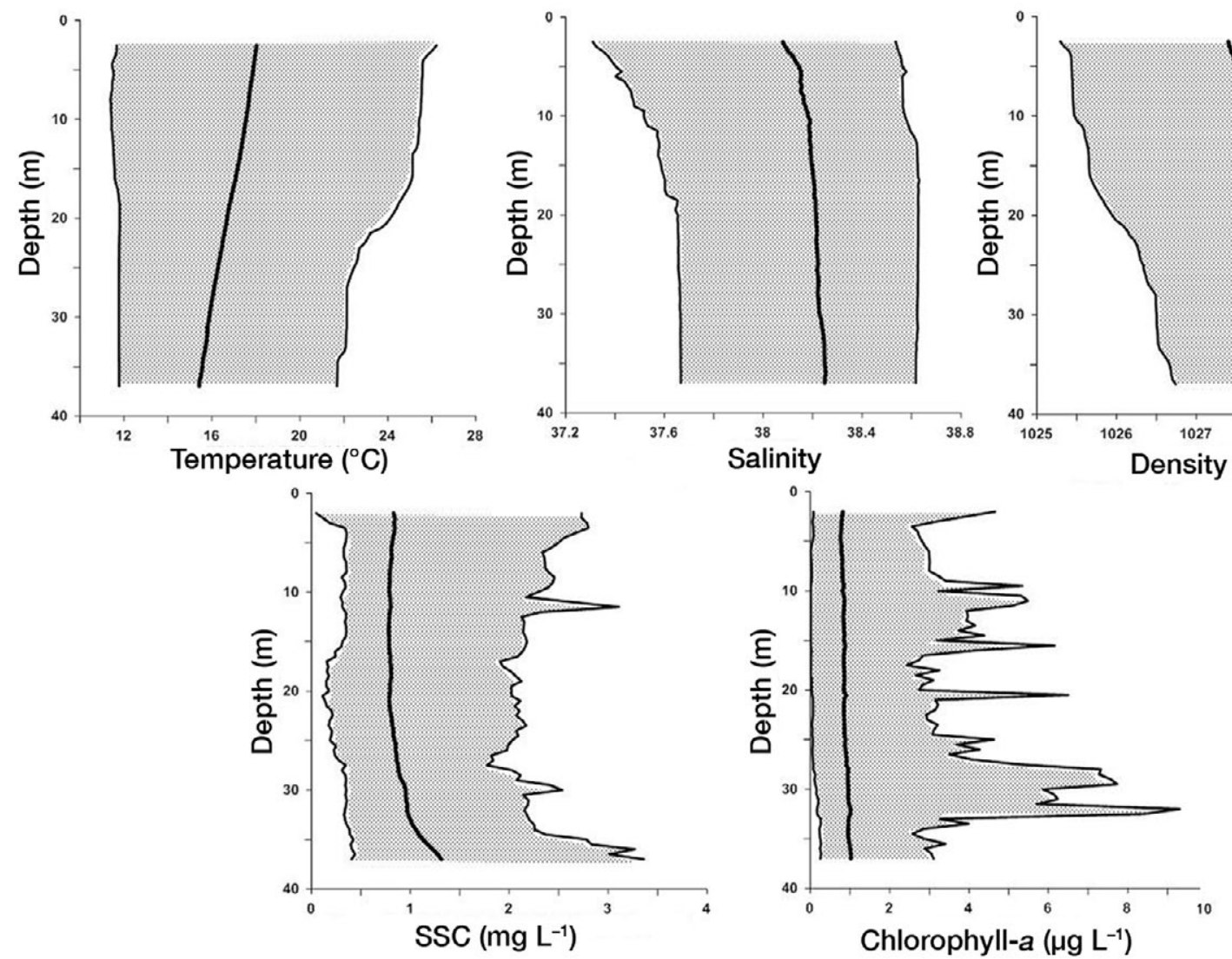

Fig. 7. - Mean, maximum and minimum values of vertical profiles of measured variables at station 1.4.

period, when a well-developed thermocline was present, whereas during the winter period, when the water column was homogeneous, the standard deviation was almost negligible $\left(\mathrm{sd}<0.5^{\circ} \mathrm{C}\right)$ (Fig. 6).

The monthly averaged vertical profiles of temperature displayed an almost straight shape during winter conditions (November to March). In April, warming of the most superficial layer started and progressively affected deeper waters during the following months, reaching the maximum vertical gradient in August. The progressive cooling of the surface layer started in September and the stratification eroded progressively until vertical homogeneity was reached in November (Fig. 8).

\section{Salinity}

The mean absolute salinity measured at station 1.4 was 38.19 , ranging from 37.59 to 38.60 . Salinity time series also displayed strong seasonality, with the maximum in winter and the minimum in spring (Figs 4, 5 and $6)$. The average monthly distribution shows that maximum salinity $(>38)$ occurred during the winter. from November to March, when values were almost vertically homogeneous. Minimum salinity values were reached in May and June, with the freshest surface waters occurring in June (Fig. 4). The vertical gradient of the salinity increased during the summer ( $\mathrm{sd}>0.1)$ because of the water stratification (Fig. 6), whereas the average monthly profiles show a straight shape from November to March (data not shown), as also occurred for temperature.

\section{Water density}

Extreme measurements of water density at station 1.4 were 1025.162 and $1029.37 \mathrm{~kg} \mathrm{~m}^{-3}$ during the study period, and the depth-averaged water density at the same station ranged from 1026.22 to $1029.25 \mathrm{~kg}$ $\mathrm{m}^{-3}$. As expected from the behaviour of temperature and salinity, water density displayed a marked seasonality, with denser waters in winter and lighter waters in summer (Figs 4, 5 and 6). The average monthly distribution of the density shows a minimum density in August-September in coincidence with the temperature maxima, an increasing trend until it reached its

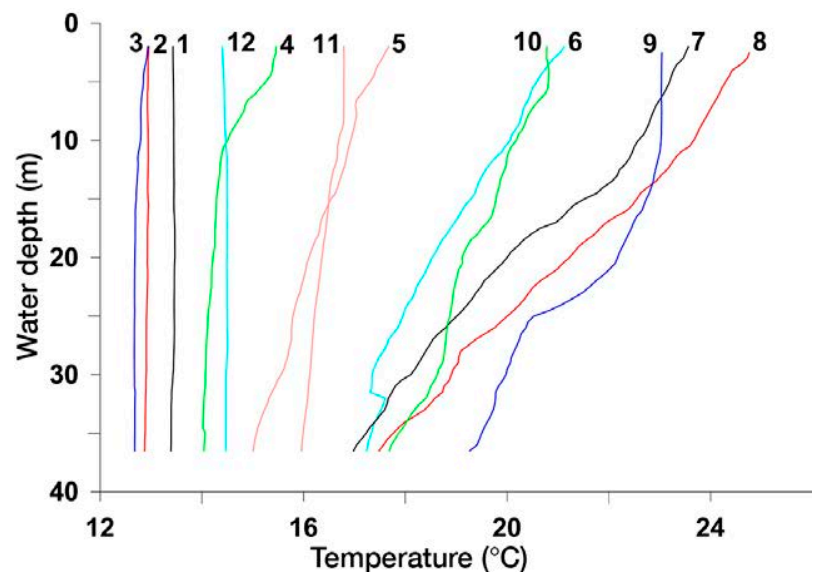

Fig. 8. - Averaged monthly temperature vertical profiles at station 1.4 (numbers indicate the month). 
maximum in February-March, and again a decreasing trend towards the summer (Fig. 4). The mean annual vertical profile shows that density increased with depth (Fig. 7), but there was a strong vertical gradient of the density in summer $\left(\mathrm{sd}>0.5 \mathrm{~kg} \mathrm{~m}^{-3}\right)$, whereas in winter it was almost negligible $\left(\mathrm{sd}<0.1 \mathrm{~kg} \mathrm{~m}^{-3}\right)$ (Fig. 6).

\section{Suspended sediment concentration}

The mean SSC in Barcelona coastal waters (represented by station 1.4) was $0.87 \mathrm{mg} \mathrm{L}^{-1}$, with minimum concentrations of $0.04 \mathrm{mg} \mathrm{L}^{-1}$ and maximum concentrations of $15.5 \mathrm{mg} \mathrm{L}^{-1}$. Time series or averaged monthly data (Figs 4, 5 and 6) show no evident seasonal variability of SSC. The averaged profile displayed an increase in SSC towards the seabed (Fig. 7). Several peaks of near-bottom SSC ( $\left.>2 \mathrm{mg} \mathrm{L}^{-1}\right)$ were recorded in May-June and September-October, and were probably related to rainfall periods. However, events of bottom sediment resuspension caused by surface wave activity or strong wind-induced currents were not captured during the surveys because it was impossible to go out with the boat during rough sea conditions, so they are unlikely to affect the present time series significantly.

\section{Chlorophyll a}

In the upper water layers, chlorophyll $a$ displayed a marked annual cycle with maximum monthly mean values in March-April, a smaller peak around November and the lowest concentrations between July and October, although there was great variability during the year (Fig. 9A). Vertical profiles of chlorophyll $a$ tended to be homogeneous during winter, but at station 1.4, between June and September, there was a marked increase in the chlorophyll $a$ concentration below $20 \mathrm{~m}$ depth (Fig. 9B), which could also be noted as a peak in the maximum values of the pooled profile data (Fig.
7). Estimations of the depth-averaged content of chlorophyll $a$ at station 1.4 ranged between 0.13 and 2.84 $\mu \mathrm{g} \mathrm{L}^{-1}$, and its mean value during the study period was $0.87 \mu \mathrm{g} \mathrm{L}^{-1}$ (Figs 5 and 6). Peak values occasionally reached more than $6 \mu \mathrm{g} \mathrm{L}{ }^{-1}$, as in March 2006 and September 2011.

\section{Interannual variability and trends}

Temperature, salinity and water density displayed interannual changes with no obvious long-term trend (Figs 5 and 6). Yearly averaged values of these variables within the study period show a maximum temperature in 2006 and salinity and density maxima in 2005 (Fig. 10). Minimum annual temperatures occurred in 2004 and 2010, minimum salinity in 2011 and minimum density in 2008. Data from 2002 were not considered because of the lack of data in JanuaryMarch 2002.

In order to better identify potential temporal trends, the slope of the linear regression fitting was calculated. The values of the slope, the $95 \%$ confidence interval and the p-values are displayed in Table 3. Since the p-values are clearly above 0.05 (except for SSC and chlorophyll $a$ ), it can be concluded that temperature, salinity and density data showed no significant increasing (or decreasing) trend, while chlorophyll $a$ and SSC showed a small but significant decreasing trend.

\section{DISCUSSION}

\section{Temporal variability}

Seawater properties in the Barcelona coastal area display the characteristic seasonal cycle of the coastal waters of the NW Mediterranean (Salat et al. 2002). The warming period starts in March-April with a progressive stratification, reaching a maximum sur-
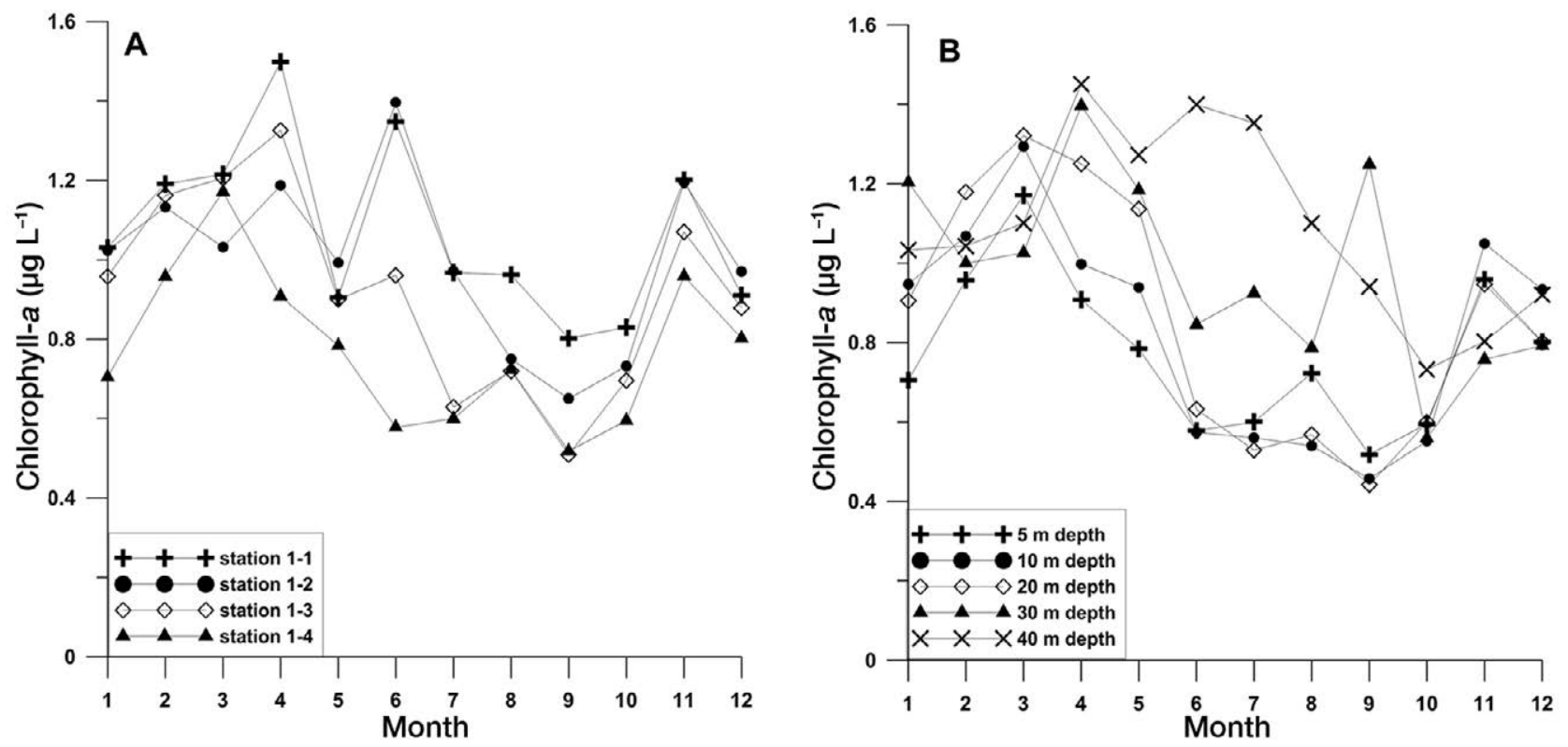

Fig. 9. - A, annual distribution of the monthly mean of chlorophyll $a$ at $5 \mathrm{~m}$ depth for stations 1.1, 1.2, 1.3 and 1.4. B, annual distribution of the monthly mean of chlorophyll $a$ at 5, 10, 20,30 and $40 \mathrm{~m}$ depth for station 1.4. 


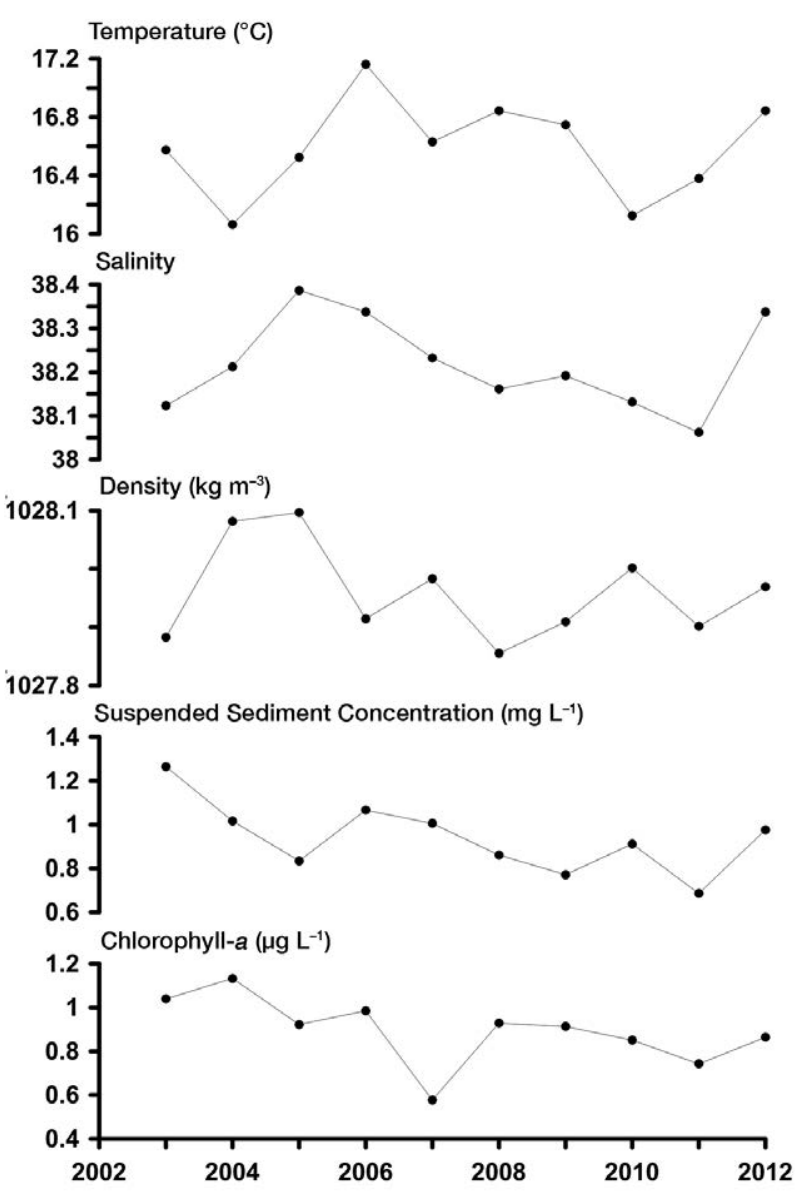

Fig. 10. - Yearly evolution of variables measured at station 1.4 (data from year 2002 not shown because they were biased by the absence of measurements during the January-February period).

face temperature in August. Then, surface cooling and wind-driven vertical mixing in the autumn (late October-November) break the seasonal thermocline, leading to vertical homogenization. Cooling of the whole water column by convection and vertical mixing continues during the winter (December to February) until the start of the next warming cycle in March (Figs 5 and 8). The salinity pattern is characteristic of areas where freshwater inputs are scarce enough to be able to generate significant changes in the salinity of the coastal waters. However, strong winds in winter also favour vertical mixing and evaporation, causing an increase in salinity (Figs 4, 5 and 6). The seasonal cycle of surface chlorophyll $a$ concentration is typical of the Mediterranean coast (Siokou-Frangou et al. 2010, Nunes et al. 2018). However, integrated values at the deep station display a different seasonal pattern because they include the contribution of near-bottom layers of high chlorophyll $a$, a feature that has been associated with enhanced nutrient availability (Guallar and Flos 2017).

The absence of interannual trends in time series of temperature, salinity and density in Barcelona during the period 2002-2012 is consistent with observations of meteorological variables and seawater temperature in different Mediterranean areas. For instance, the mean monthly air temperature in Barcelona city displayed a seasonal oscillation with earlier peaks (1-2 months before) and greater variability than depth-averaged seawater temperature, but no long-term trend was observed (Fig. 11). Additionally, the comparison between Barcelona time series and the averaged water temperature (0-35 m water depth) measured at L'Estartit station [located about $150 \mathrm{~km}$ north of Barcelona, see Salat and Pascual (2002) for a detailed explanation of methods and results at this coastal station] showed that the two series followed the same seasonal pattern had similar absolute values and displayed no long-term trends during the study period (Fig. 11). Although a long-term water warming was described from the whole 40-year time series at L'Estartit by VargasYáñez et al. (2008, 2010), this trend is much less clear if only the 20-year period (1991-2011) is taken into account. As pointed out by these authors, warming trends are neither linear nor constant processes, and oscillations of different periods can be superimposed on the general trend, producing an apparent hiatus. Therefore, no significant temporal trends in water temperature, salinity and density were detected in the coastal waters off Barcelona in the period 2002-2012, one possible reason being that 11 years is too short a time span to detect long-term trends.

The significant interannual (decreasing) trends of SSC and chlorophyll $a$ should be interpreted with caution, because mean SSC and chlorophyll $a$ values are low, indicating very restricted sedimentary inputs in coastal waters from rivers and city outfalls as well as general oligotrophic conditions. SSC time series show values lower than $5 \mathrm{mg} \mathrm{L}^{-1}$ except for some water levels near the bottom and the surface during the period March to June 2004 (Fig. 5). Chlorophyll $a$ concentrations in the time series samples show a maximum sample value of $9.3 \mu \mathrm{g} \mathrm{L} \mathrm{L}^{-1}$, but typically remain below $1 \mu \mathrm{g} \mathrm{L}^{-1}$. In addition, these mean low concentrations make the results very sensitive to the sensor properties and calibration equations. It must be taken into account, in this context, that both turbidity and fluorescence were measured using different sensors during the observation period (see methods). Therefore, although the decreasing trends of SSC and chlorophyll $a$ were statistically significant, they could have been affected by errors and imprecisions in calibrations associated with the change of sensors in the period 2002-2012.

Table 3. Interannual trends during the study period.

\begin{tabular}{lccc}
\hline & Trend (units/year) & 95\% confidence & p-value \\
\hline Temperature & +0.025 & -0.171 to +0.222 & 0.79, not significant \\
Salinity & +0.0009 & -0.01 to +0.012 & 0.87, not significant \\
Density & -0.0047 & -0.05 to +0.04 & 0.85, not significant \\
SSC & -0.0214 & -0.036 to +0.006 & 0.005, significant \\
Chlorophyll $a$ & -0.028 & -0.055 to -0.002 & 0.034, significant \\
\hline
\end{tabular}



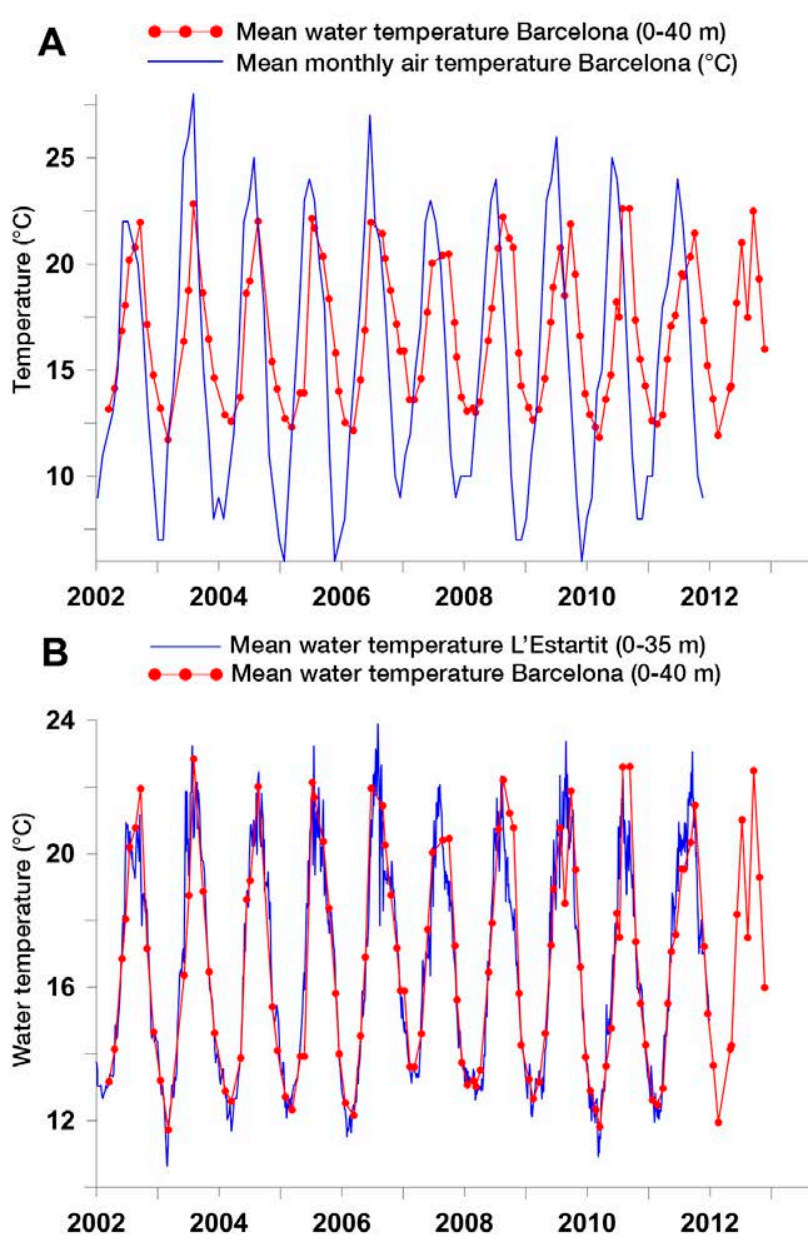

Fig. 11. - Comparison between A, time series of water and air temperature in Barcelona and B, water temperature at Barcelona and L'Estartit (located about $150 \mathrm{~km}$ to the northeast) coastal stations (water temperature in both graphs corresponds to station 1.4 and is represented by the dotted line).

Other potential forcing factors such as river discharges (and associated nutrient discharges), rainfall and wave climate displayed no interannual trend during the study period (Fig. 3), but one possible source of variability that cannot be excluded is the effect of water treatment plants that clean waste waters of the Barcelona city area, since the largest plants are located at both sides of the study area, near the Llobregat and Besòs rivers (Fig. 1) and they were expanded and improved in 2003 and 2005, respectively.

\section{Marine heat wave events}

The highest mean daily air temperatures in the study period were measured in July and August $2003\left(31^{\circ} \mathrm{C}\right.$ and $33^{\circ} \mathrm{C}$, respectively). In fact, five of the ten daily maximum temperatures recorded in Barcelona city during the whole last century (1914-2013) occurred in August 2003 (http://www.fabra.cat/meteo/). The heat wave of summer 2006 was also characterized in Barcelona by the maintenance of high temperatures during a long period (September-December 2006). This finding is consistent with the description of the heat wave of 2006 in Europe, which was due not only to the high air temperature in summer but also to the milder than usual temperature during the period September 2006 to February 2007 (Luterbacher et al. 2007).

The seawater temperatures recorded in Barcelona during the heat episodes of 2003 and 2006 were quite similar, although the warmest month of our series was August 2003 (Figs 6 and 12) and the warmest year 2006 (Fig. 10). The highest seawater temperature was also recorded in August $2003\left(26.21^{\circ} \mathrm{C}\right.$ at $2.5 \mathrm{~m}$ water depth), although extreme temperatures higher than $25^{\circ} \mathrm{C}$ were present in the shallower records of the water column in 6 of the 11 summers $(2003,2005,2006$, 2008, 2009 and 2010), suggesting that the presence of very warm coastal waters is quite usual during the summer period. Interestingly, the minimum and maximum depth-averaged seawater temperatures recorded at station 1.4 (40 $\mathrm{m}$ depth) were in the same year, making the strongest temperature contrast of the study period between $11.73^{\circ} \mathrm{C}$ and $22.83^{\circ} \mathrm{C}$, in March and August 2003 , respectively. The winter heat loss that produces extreme cold water episodes on the continental shelf is mainly caused by cold and dry northerly winds, which are enhanced by an anticyclonic anomaly in the North Atlantic and a cyclonic anomaly over the Baltic Sea that favours strong, cold, and dry winds in this area (Durrieu de Madron et al. 2013). The extreme heat wave in 2003 was caused by the northward shift of the polar jet, which allowed the anticyclone to expand over central Europe (Feudale and Shukla 2011). However, there is no obvious relation between cold and warm events.

Marine heat waves are usually defined on the basis of threshold temperatures (typically 90th percentile) extracted from time series at a specific site for a minimum length (typically 3-5 days) (Hobday et al. 2016, Schlegel et al. 2017). Consequently, the frequency and duration of the Barcelona time series would make it difficult to identify most of these episodes. To check the possibility of identifying the most extreme events during the study period we estimated de $2^{\text {nd }}$ and $98^{\text {th }}$ percentiles of temperature at 5 and $20 \mathrm{~m}$ water depth. Threshold temperatures were $11.99 / 11.99^{\circ} \mathrm{C}$ and $25.29 / 22.88^{\circ} \mathrm{C}$ at $5 / 20 \mathrm{~m}$ water depth, respectively. Cold water episodes occurred at 5 and $20 \mathrm{~m}$ water depth in March 2003, March 2010 and February 2012 and were identified simultaneously along the water column. The occurrence of marine heat waves based on these criteria would depend on the selected water depth. Warm episodes were identified at $5 \mathrm{~m}$ water depth in August 2003, July 2005 and September 2006. By contrast, warm episodes at $20 \mathrm{~m}$ depth were identified in September 2008 and August and September 2010. The different behaviour between cold and heat events is due to the homogeneity of the water column in winter and its strong stratification in summer. The maximum temperatures in surface waters are directly caused by radiation and atmospheric heat flux in JulyAugust, whereas the maximum temperatures at $20 \mathrm{~m}$ water depth occur later (September), as a consequence of deepening of the upper mixed layer caused by surface heat loss and/or wind/wave-induced mixing (Fig. 8). This different timing in the maximum temperature 


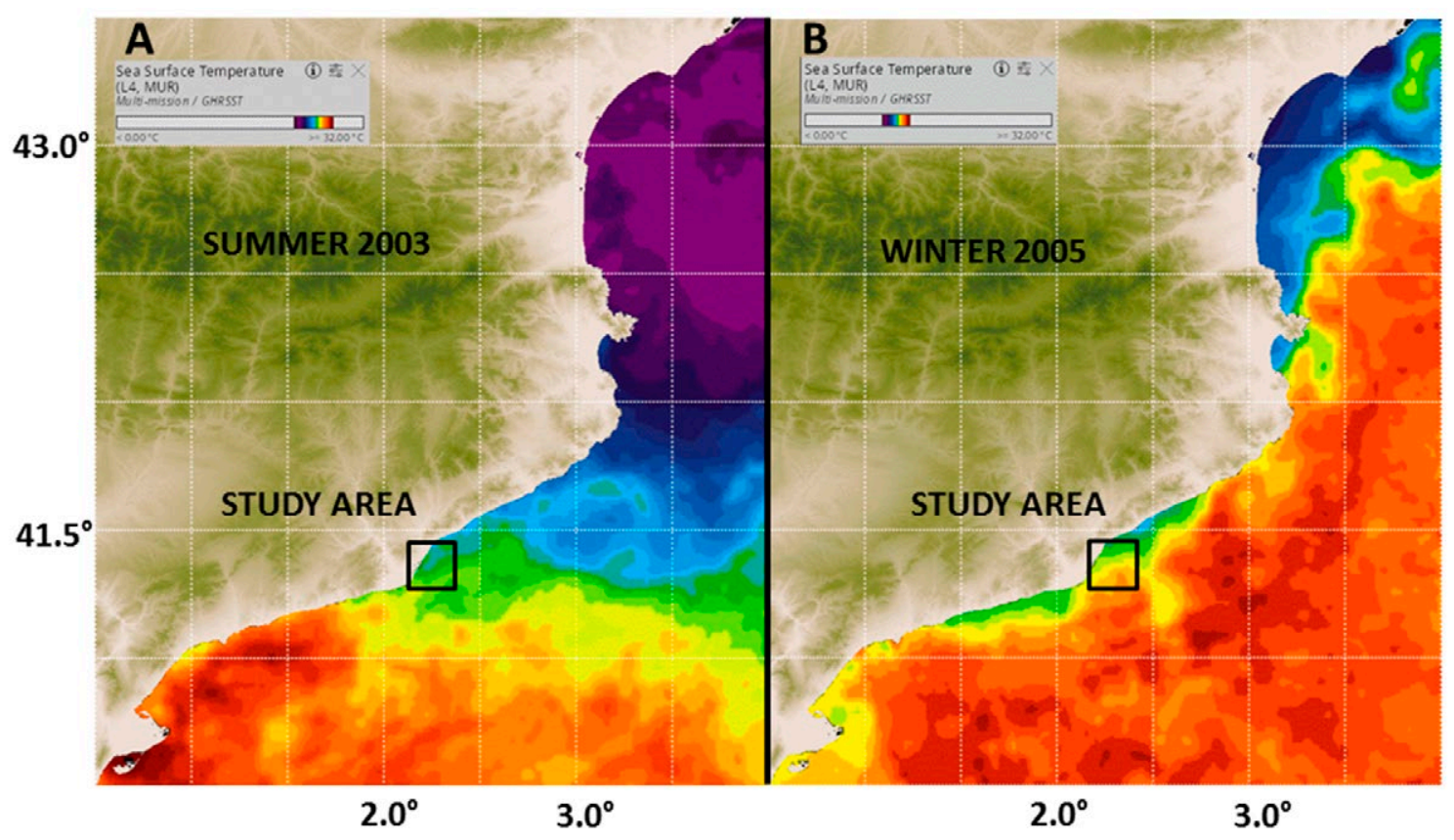

Fig. 12. - Sea surface temperature charts. A, wave heat in summer 2003 (14 July 2003) (temperature scale: $23-28^{\circ} \mathrm{C}$ ) and B, Dense water formation event in winter 2005 (19 February 2005) (temperature scale: 10-13.5 ${ }^{\circ}$ ).(Images from GHRSST Sea Surface Temperature Level 4, Multi-scale Ultra-high Resolution, NASA, https://worldview.earthdata.nasa.gov/).

along the water column should be taken into account in the evaluation of potential impacts of marine wave heats on the biological communities.

Coma et al. (2009) suggested a seawater temperature threshold of $18^{\circ} \mathrm{C}$ at $20 \mathrm{~m}$ depth as a good indicator of marine "summer conditions" at L'Estartit coastal station, because during the 40-year time series available there it was a value above which the thermocline was not broken by any perturbation. This means that when this temperature is reached at $20 \mathrm{~m}$ depth, stratification is consolidated and remains until the end of summer. To illustrate the application of this observation to Barcelona waters, we compared the temperature at $20 \mathrm{~m}$ water depth of station 1.4 and the stratification of the water column, represented by the standard deviation of the density profile (the Brunt-Väisälä frequency was also checked but it did not really add any information to the general description of temporal variability of the stratification and mixing) (Fig. 13). In general, the highest temperatures corresponded to high standard deviation in the 40-m water column, but the relation between the two variables was far from linear, especially at the beginning and the end of the stratification period. In some years, there was a strong stratification in MayJune but the isocline of $18^{\circ} \mathrm{C}$ was shallower than 20 $\mathrm{m}$. Conversely, in September-October the thermocline was deeper than the 40-m water column of our control profile, and the stratification of shallower waters was low (but the temperature was very high).

In spite of these uncertainties, we applied the criterion regarding water stratification proposed by Coma et al. (2009) to L'Estartit data as a simple tool for measuring the duration of the "summer" conditions mentioned above. Following this criterion, the permanent stratification of the water column at L'Estartit occurred between 99 and 174 days per year during the study pe- riod. This well-developed stratification had a duration of 122 and 152 days in 2003 and 2006, respectively. However, the maximum persistence of water temperatures higher than $23^{\circ} \mathrm{C}$ at $20 \mathrm{~m}$ depth at L'Estartit station (45 days during the study period) matched with the warmest years (15 days in summer 2003 and 20 days in summer 2006) (Fig. 14). Although a direct relation between increased sea surface temperature (coupled with decreased rainfall and wind) and an ex-

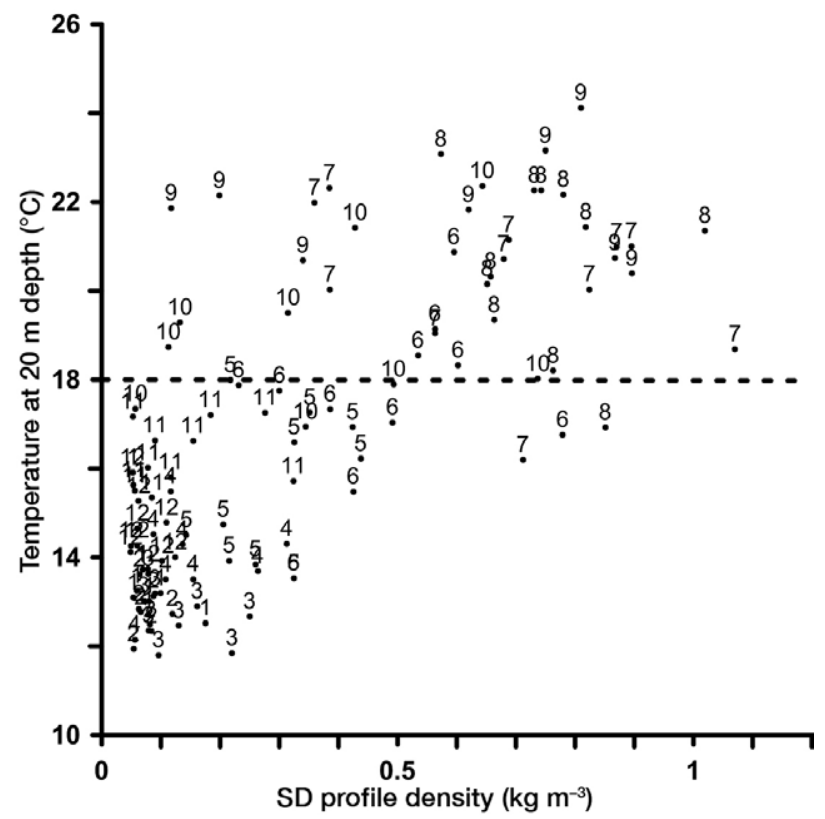

Fig. 13. - Comparison between the temperature at $20 \mathrm{~m}$ depth as an indicator of stable stratification (Coma et al. 2009) and the standard deviation (SD) of the vertical profile of density at station 1.4 (numbers indicate the month of the year). 


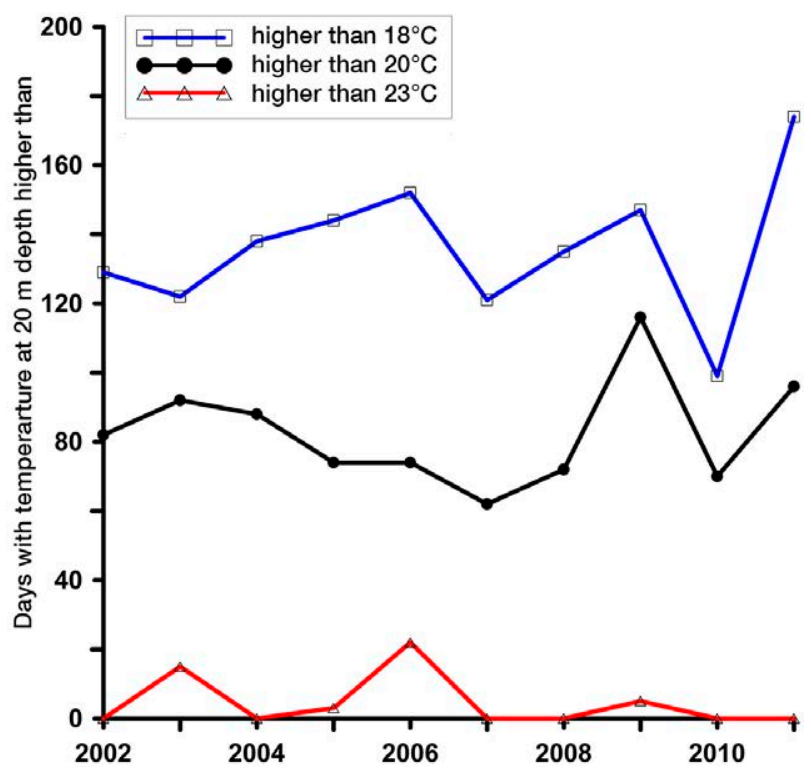

Fig. 14. - Days with fully developed water stratification based on water temperature at $20 \mathrm{~m}$ depth measured at L'Estartit coastal station.

tended stratification period, with implications for the definition of future climate change scenarios, has been described (Calvo et al. 2011), this was not observed in the analysed data. This would suggest that, in addition of the seasonal heating by radiation, the freshwater inputs and the intensity of mixing processes driven by waves, winds or oceanic circulation conditions should be taken into account for understanding the processes involved in the onset and overturn of stratification periods (Cheng et al. 2010, Magee and Wu 2017).

Therefore, seawater temperatures during the 2003 and 2006 summers show no obvious differences that could explain why a negative impact on the benthic ecosystem of the western Mediterranean occurred only in summer 2003 (Garrabou et al. 2009). As pointed out by Coma et al. (2009), the combination of extremely high temperatures and a long duration of the stratified period was probably what caused the mortality event of 2003, because higher temperature accelerated the metabolism, and stratification limited the availability of food. The main singularities of the year 2003 were the persistence of extreme seawater temperatures, the contrast between the coldest water in March and the warmest in August, and the strong storm episodes that occurred, mainly during the prolonged events in October. As stated in previous studies, ecosystem response has a non-linear relation with temperature, and simplistic interpretations of the effect of temperature increase on marine ecosystems should be avoided (Garrabou et al. 2009, Brander 2013, Brochier et al. 2013). Our observations at the Barcelona station suggest that the persistence of extreme seawater temperatures $\left(>25.29^{\circ} \mathrm{C}\right.$ at $5 \mathrm{~m}$ water depth or $>22.88^{\circ} \mathrm{C}$ at $20 \mathrm{~m}$ water depth and $<11.99^{\circ} \mathrm{C}$ at both depths) will make it possible to identify future extreme heat and cold wave events in the Barcelona coastal area. These thresholds correspond respectively to the $2^{\text {nd }}$ and $98^{\text {th }}$ percentile of the temperature recorded at 5 and $20 \mathrm{~m}$ water depth over the decade.

\section{Dense water formation events}

The T/S diagram from the CTD profiles collected off Barcelona shows a wide range of variability of temperature, salinity and density of the water masses during the study period, which is a common characteristic of coastal waters (Figs 12 and 15). Most measurements have properties of "old" Atlantic Water (oAW) or Continental Shelf Water (CSW) as defined in Salat et al. (2006), although some very dense waters (>1029 $\mathrm{kg} \mathrm{m}^{-3}$ ) found in the coastal region off Barcelona had properties characteristic of deeper water masses (Table $1)$. The highest density recorded in Barcelona coastal waters occurred in February-March 2005, JanuaryMarch 2006 and March 2012, all periods corresponding to strong cascading or deep convection processes in the Gulf of Lions region (Salat et al. 2006, Palanques et al. 2012, Durrieu de Madron et al. 2013).

In the winter 2005 event, the dense shelf water cascading was observed at the head of the Cap de Creus Canyon in late December 2004. From late February to late March 2005, cascading occurred uninterruptedly and affected areas deeper than $750 \mathrm{~m}$ (Canals et al. 2006, Font et al. 2007, Puig et al. 2008). In the coastal zone of Barcelona, water densities greater than 1029 $\mathrm{kg} \mathrm{m}^{-3}$ were observed at least from early February to mid-March, with the highest density on 15 March $2005\left(1029.25 \mathrm{~kg} \mathrm{~m}^{-3}\right)$. The transfer of dense waters from the Gulf of Lions towards the south along the Catalan continental shelf during the 2004-2005 event was reproduced by some oceanographic models (Ulses et al. 2008). These coastal dense waters can cascade downslope along their path and could be partially replenished by intrusions of slope waters over the shelf.

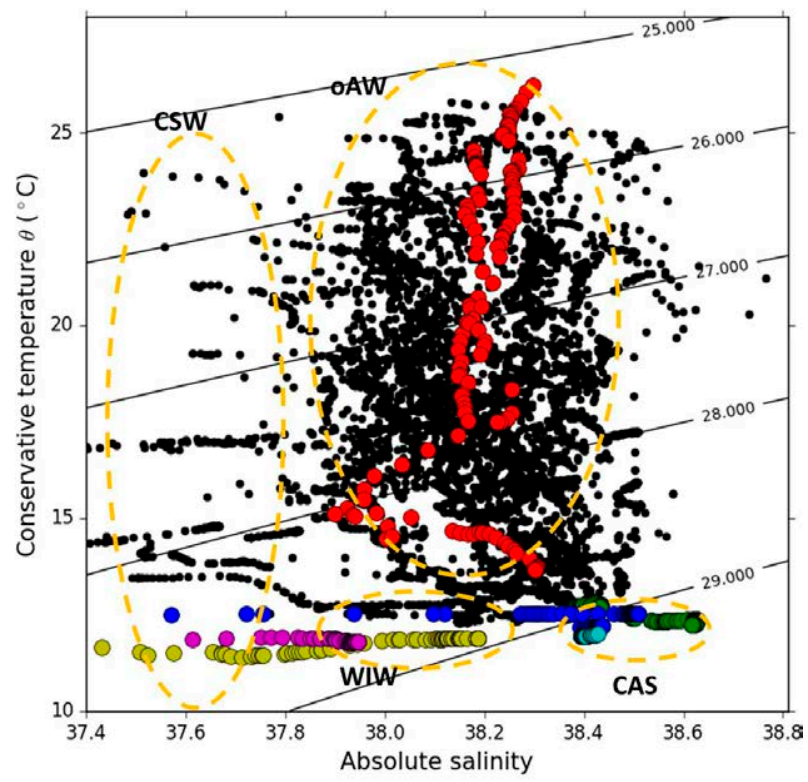

Fig. 15. - T/S diagram including all data from time series at station 1.4 showing main events and water masses. (CSW, Continental Shelf Waters; oAW, old Atlantic Water; WIW, Western Intermediate Water; CAS, Main events of dense water formation. Green dots, March 2005 event; blue dots, March 2006 event; cyan dots; March 2012 event; magenta dots, March 2010; yellow dots, March 2003 cold wave event; red dots, August 2003 heat wave event). Note the freshwater influence in the March 2003, 2006 and 2010 events. 
In March 2005, Salat et al. (2006) identified water masses generated by shelf-cascading from a CTD section near the shelf break off Barcelona and suggested that such dense waters could favour the rise of LIW close to the surface, which is eventually brought over the continental shelf and therefore causes the neardisappearance of the typical shelf-slope front (Salat et al. 2006, 2009).

During the winter 2006 event in the NW Mediterranean, deep-reaching cascading pulses occurred in early January, late January and from early March to mid-April 2006 in the NW Mediterranean (Palanques et al. 2012). Marty and Chiavérini (2010) and Martin et al. (2010) described an intense convection and mixing process in the Ligurian Sea in February 2006 that caused an abrupt increase in temperature and salinity through the mixing of WMDW and LIW water masses. These authors suggested that this event was preconditioned and favoured by an increase in density in shallow waters (0-200 m water depth) and especially by the 2005 event that produced a decrease in the density gradient between surface and intermediate waters. Coastal waters in the Barcelona area also reached densities higher than $1029 \mathrm{~kg} \mathrm{~m}^{-3}$ in late January and mid-March 2006.

Finally, the winter of 2012 was characterized by a significant cooling of surface water, especially on the inner and middle shelf of the Gulf of Lions, when density reached $1029.71 \mathrm{~kg} \mathrm{~m}^{-3}$ on 13 February 2012 (Durrieu de Madron et al. 2013). From 5 February to mid-March 2012 several episodes of dense shelf water cascading occurred in the southern canyons of the Gulf of Lions, with the main cascading episode on 11 February 2012. The maximum density of Barcelona coastal waters that winter reached $1029.18 \mathrm{~kg} \mathrm{~m}^{-3}$ on 22 February 2012, and values close to $1029 \mathrm{~kg} \mathrm{~m}^{-3}$ were measured in the late January and mid-March surveys.

It is important to note that the main episodes of dense water formation and cascading in the western Mediterranean during the period 2002-2012 (events occurring in 2005, 2006 and 2012) can be clearly identified in the density records of the coastal waters of Barcelona, suggesting that advection of dense water from the Gulf of Lions and the Gulf of Roses (Ulses et al. 2008, Ribó et al. 2011) may reach or influence the Barcelona shelf. These events cause the weakening or disappearance of the shelf-slope front, which in turn favours exchanges between the coastal and oceanic waters (Salat et al. 2009). In fact, observations of some biological variables showed significant changes during those periods, probably related to the anomalous hydrographic situation caused by the extreme dense water formation events (Arin et al. 2013). For instance, a massive invasion of a jellyfish (identified as Pelagia noctiluca) was observed on several beaches along the Mediterranean Spanish coast (including the Catalan coast) during the summer of 2005. Pelagia noctiluca is an oceanic species that can reach the coast favoured by currents or winds (Graham et al. 2001). According to biological sampling data obtained at the study site, the phytoplank- ton species that typically produce the winter-spring blooms (mainly diatoms of the genera Chaetoceros and Pseudo-nitzschia) were partially replaced in 2006 by other species of diatoms (Bacteriastrum cf. delicatulum, Rhizosolenia cf. imbricata) and by a massive bloom of the nanoflagellate Phaeocystis sp. (Arin et al. 2013), usually found in open-sea oceanic waters. A similar phytoplankton composition was also observed in March 2006 at other sites of the central coast of Catalonia located north of Barcelona city (Sampedro et al. 2008), suggesting that the process had a wide regional range affecting the entire coast. The atypical hydrographic characteristics observed in the winters of 2005 and 2006 (with the weakening or disappearance of the shelf-slope front), in addition to favourable wind conditions, could have been the main causes of the expansion to the Catalan coastal waters of phytoplankton and jellyfish taxa of a more oceanic nature during these years (Arin et al. 2013).

\section{CONCLUSIONS}

Monthly observations of temperature, salinity, density, SSC and chlorophyll $a$ in coastal waters of Barcelona city during an 11-year period provided a detailed picture of the temporal and spatial variability of these variables. A strong seasonal component was driven by the warming and progressive stratification of the shallow waters from April to October and the subsequent cooling, which reached a maximum in March and favoured water column mixing and exchanges between coastal and oceanic waters. The spatial (acrossshelf and water column) and temporal (seasonal and interannual) variability of oceanographic variables has been described, focusing on periods when extreme meteorological or oceanographic events were previously identified.

The absence of decadal trends in oceanographic variables of the Barcelona coastal waters during the period 2002-2012 is in agreement with other meteorological and oceanographic observations in the region, which showed no clear trends during this period. However, this finding should be contextualized in a longer-term perspective, since longer time series (several decades) of oceanographic variables in the western Mediterranean show significant trends induced by climate changes. It should also be noted that SSC and chlorophyll $a$ did show a significant decreasing trend during the study period that was unrelated to external forcing such as river water discharges, rainfall or wave activity. Although caution is needed because of potential errors induced by the calibration of different sensors, it is plausible to consider that the reduction of SSC and chlorophyll $a$ in coastal waters was due to the improvement, mainly in the 2003-2005 period, of the network of water treatment plants that clean waste waters discharging into the area.

Extreme sea water temperatures were recorded at the Barcelona station during heat waves that affected the NW Mediterranean in 2003 and 2006. Apparently, the heat wave events of 2003 and 2006 did not produce a longer period of water stratification, but just an 
increase in the number of days with extreme high temperatures. Threshold seawater temperatures of $25.29^{\circ} \mathrm{C}$ at $5 \mathrm{~m}$ water depth or $22.88^{\circ} \mathrm{C}$ at $20 \mathrm{~m}$ water depth can be approximate indicators of heat waves in the Barcelona area, whereas temperatures below $11.99^{\circ} \mathrm{C}$ in the water column correspond to cold wave episodes. It is suggested that the duration of the period of extreme warm waters in August 2003 and with the coldest observed waters in winter 2003 operated in synergy with the high temperatures to produce the harmful impact on benthic communities. The singularity of the year 2003 was also evidenced by the largest cumulative period of storm waves of the study.

The strongest episodes of shelf water cascading or deep-water convection in the western Mediterranean occurred in 2005, 2006 and 2012 and brought water densities of more than $1029 \mathrm{~kg} \mathrm{~m}^{-3}$ during the months of February and March in Barcelona coastal waters, immediately before the characteristic chlorophyll spring bloom. This fact implies that fertilization and ecological processes in coastal areas could be strongly influenced by mesoscale oceanographic processes. The presence of coastal waters with densities typical of deeper waters favours the mixing of the water column, the breaking of the shelf-slope front and the exchange between coastal and oceanic waters during these events.

The results of this study demonstrate that monthly monitoring of oceanographic variables in the coastal zone can be used to identify large-scale events such as heat waves and regional sinking of superficial waters. The maintenance of a relatively simple coastal monitoring programme provides a better understanding of coastal processes and is an additional tool for improving the short-term forecasting of large-scale events. In a long-term perspective, this information is also relevant in a global context of climate change affecting the marine environment.

\section{ACKNOWLEDGEMENTS}

The sampling was carried out in the framework of the Coastal Ocean Observatory with the support of several research projects and continued support from the Institute of Marine Sciences staff. The carrying out of more than 100 campaigns and laboratory analyses required the enthusiastic collaboration of a large number of people. Although it is impossible to list all of them, we want to give our thanks, on behalf of the participants, to Maribel Lloret, Jordi Cabot, Oriol Mulet, Neus Maestro, Silvia de Diago, Elena Martínez, Mara Abad, Jose A. Pozo, Mª Angeles Millán, Elena Ojeda, Maxi Delgado, Cesca Ribas, Laura López, Mariona Segura, Marc Belzunzes, Amanda Sancho, Alberto Arias and Xavi Vidal, among many others who supported the surveys and analyses. The sampling also received funding from the HABES (Ref. EVK2-CT-2000-00092), PUDEM (Ref.REN200306637-C02) and SEDMET (Ref. CTM2006-06919) projects. JG, PP, GS and AP belong to the CRG on Littoral and Oceanic Processes, supported by Grant 2014 SGR 1642 of the Generalitat of Catalonia.

\section{REFERENCES}

Arin L., Guillén J., Segura-Noguera M., et al. 2013. Open sea hydrographic forcing of nutrient and phytoplankton dynamics in a Mediterranean coastal system. Estuar. Coast Shelf Sci. 133: 116-128. https://doi.org/10.1016/j.ecss.2013.08.018

Brander K.M. 2013. Climate and current anthropogenic impacts on fisheries. Clim. Chang. 119: 9-21. https://doi.org/10.1007/s10584-012-0541-2

Brochier T., Echevin V., Tam J., et al. 2013. Climate change scenarios experiments predict a future reduction in small pelagic fish recruitment in the Humboldt current system. Global Chang. Biol. 19: 1841-1853. https://doi.org/10.1111/gcb.12184

Calvo E., Simó R., Coma R., et al. 2011. Effects of climate change on Mediterranean marine ecosystems: the case of the Catalan Sea. Clim. Res. 50: 1-29. https://doi.org/10.3354/cr01040

Canals M., Puig P., Durrieu de Madrou X., et al. 2006. Flushing submarine canyons. Nature 444: 354-357. https://doi.org/10.1038/nature05271

Carniel S., Wolf J., Brando V.E., et al. 2017. Preface: Oceanographic processes on the continental shelf: observations and modelling. Ocean Sci. 13: 495-501. https://doi.org/10.5194/os-13-495-2017

Castellà M., Brunet M. 2011. Study of the heat wave of the summer 2003 at the Mediterranean coast of the Iberian Peninsula. Tethys 8: 89-99.

CIESM 2002. Tracking long-term hydrological change in the Mediterranean Sea. In: Briand F. (ed.), CIESM Workshop Series 16, Monaco, $134 \mathrm{pp}$.

CIESM 2008. Towards an integrated system of Mediterranean marine observatories. In: Briand F. (ed.), CIESM Workshop Monographs, 34, Monaco, $144 \mathrm{pp}$.

Cheng P., Valle-Levinson A., Winant C.D., et al. 2010. Upwellingenhanced seasonal stratification in a semiarid bay. Cont. Shelf Res. 30: 1241-1249. https://doi.org/10.1016/j.csr.2010.03.015

Coma R., Ribes M., Serrano E., et al. 2009. Global warming-enhanced stratification and mass mortality events in the Mediterranean. Proc. Natl. Acad. Sci. USA 106: 6176-6181. https://doi.org/10.1073/pnas.0805801106

Company J.B., Puig P., Sardà F., et al. 2008. Climate Influence on Deep Sea Populations. PLoS ONE 3: e1431. https://doi.org/10.1371/journal.pone.0001431

Crisci C., Bensoussan N., Romano J.-C., et al. 2011. Temperature Anomalies and Mortality Events in Marine Communities: Insights on Factors behind Differential Mortality Impacts in the NW Mediterranean. PLoS ONE 6: e23814. https://doi.org/10.1371/journal.pone.0023814

Dufau-Julliand C., Marsaleix P., Petrenko A., et al. 2004. Threedimensional modeling of the Gulf of Lion's hydrodynamics (northwest Mediterranean) during January 1999 (MOOGLI3 Experiment) and late winter 1999: Western Mediterranean Intermediate Water's (WIW's) formation and its cascading over the shelf break. J. Geophys. Res. 109: C11002. https://doi.org/10.1029/2003JC002019

Durrieu de Madron X., Zervakis V., Theocharis A., et al. 2005. Comments on "cascades of dense water around the World Ocean”. Prog. Oceanogr. 64: 83-90. https://doi.org/10.1016/j.pocean.2004.08.004

Durrieu de Madron X., Houpert L., Puig P., et al. 2013. Interaction of dense shelf water cascading and open-sea convection in the northwestern Mediterranean during winter 2012. Geophys. Res. Lett. 40: 1379-1385. https://doi.org/10.1002/grl.50331

Estrada M. 1996. Primary production in the northwestern Mediterranean. Sci. Mar. 60: 55-64.

Estrada M., Álvarez E., Barragán A., et al. 2008. Reflexiones sobre la gestión y custodia de datos oceanográficos en España. Recursos existentes y recomendaciones para el futuro. (ID. PCI2005-A5-0141). SCOR, Comité Científico sobre Investigación Oceánica. Prog. Actividad SCOR en España. Ministerio de Ciencia e Innovación, 42 pp.

Fernández de Puelles M.L., Molinero J.C. 2008. Decadal changes in hydrographic and ecological time-series in the Balearic Sea (western Mediterranean), identifying links between climate and zooplankton. ICES J. Marine Sci. 65: 311-317. https://doi.org/10.1093/icesjms/fsn017 
Feudale L., Shukla J. 2011. Influence of sea surface temperature on the European heat wave of 2003 summer. Part I: an observational study Most European regions were subject to abnormally dry conditions in spring and particularly in summer of 2003. Clim. Dyn. 36: 1691-1703.

https://doi.org/10.1007/s00382-010-0788-0

Fieux M. 1974. Formation d'eau dense sur le plateau du golfe du Lion. Processus de formation des eaux profondes. Colloq. Int. CNRS 215: 165-174.

Font J. 1987. The path of the Levantine Intermediate Water to the Alboran Sea. Deep-Sea Res. 34: 1754-1755.

Font J., Salat J., Tintoré J. 1988. Permanent features of the circulation in the Catalan Sea. Oceanol. Acta S9: 51-57.

Font J., Puig P., Salat J., et al. 2007. Sequence of hydrographic changes in NW Mediterranean deep water due to the exceptional winter of 2005. Sci. Mar. 71: 339-346. https://doi.org/10.3989/scimar.2007.71n2339

Garrabou J., Coma R., Bensoussan N., et al. 2009. Mass mortality in Northwestern Mediterranean rocky benthic communities: effects of the 2003 heat wave. Global Chang. Biol. 15: 1090-1103. https://doi.org/10.1111/j.1365-2486.2008.01823.x

Gori A., Orejas C., Madurell T., et al. 2013. Bathymetrical distribution and size structure of cold-water coral populations in the Cap de Creus and Lacaze-Duthiers canyons (northwestern Mediterranean). Biogeosciences 10: 2049-2060. https://doi.org/10.5194/bg-10-2049-2013

Graham W.M., Pagès F., Hamner W.M. 2001 A physical context for gelatinous zooplankton aggregations: a review. Hydrobiologia 451: 199-212. https://doi.org/10.1023/A:1011876004427

Guallar C., Flos J. 2017. Enhanced primary production in summer and winter-spring seasons in a populated NW Mediterranean coastal ecosystem. J. Sea Res. 120: 1-12. https://doi.org/10.1016/j.seares.2016.10.009

Hobday A.J., Alexander L.V., Perkins S.E., et al. 2016. A hierarchical approach to defining marine heatwaves. Prog. Oceanogr. 141: $227-238$ https://doi.org/10.1016/j.pocean.2015.12.014

IOC, SCOR, IAPSO. 2010. The international thermodynamic equation of seawater - 2010: Calculation and use of thermodynamic properties. Intergovernmental Oceanographic Commission, Manuals and Guides No. 56, UNESCO, 196 pp.

Krahmann G., Schott F. 1998. Long-term increase in western Mediterranean salinities and temperatures: Anthropogenic and climatic sources, Geophys. Res. Lett. 25: 4209-4212. https://doi.org/10.1029/1998GL900143

Lacombe H., Tchernia P. 1971-1972. Le problème de la formation des aux marines profondes. Déroulement du phénomène en Méditerranée nord-occidentale par hiver très froid (Janvier-Mars 1963). Ann. Inst. Océanogr. 48: 75-110.

Lopez-Jurado J.L., González-Pola C., Vélez-Belchí P. 2005. Observation of an abrupt disruption of the long-term warming trend at the Balearic Sea, western Mediterranean Sea, in summer 2005. Geophys. Res. Lett. 32: L24606. https://doi.org/10.1029/2005GL024430

Luterbacher J., Dietrich D., Xoplaki E., et al. 2004. European seasonal and annual temperature variability, trends and extremes since 1500. Science 303: 1499-1503. https://doi.org/10.1126/science.1093877

Luterbacher J., Liniger M.A., Menzel A., et al. 2007. Exceptional European warmth of autumn 2006 and winter 2007: Historical context, the underlying dynamics, and its phenological impacts, Geophys. Res. Lett. 34: L12704. https://doi.org/10.1029/2007GL02995

Magee M.R., Wu C.H. 2017. Response of water temperatures and stratification to changing climate in three lakes with different morphometry. Hydrol. Earth Syst. Sci. 21: 6253-6274. https://doi.org/10.5194/hess-21-6253-2017

Marbà N., Duarte C. 2010. Mediterranean warming triggers seagrass (Posidonia oceanica) shoot mortality. Global Change Biol. 16: 2366-2375. https://doi.org/10.1111/j.1365-2486.2009.02130.x

Martín J., Miquel J.-C., Khripounoff A. 2010. Impact of open sea deep convection on sediment remobilization in the western Mediterranean. Geophys. Res. Lett. 37: L13604. https://doi.org/10.1029/2010GL043704

Martin P., Maynou F., Recasens L., et al. 2016. Cyclic fluctuations of blue whiting (Micromesistius poutassou) linked to open-sea convection processes in the northwestern Mediterranean. Fish. Oceanogr. 25: 229-240 https://doi.org/10.1111/fog.12147

Marty J.C., Chiavérini J. 2010. Hydrological changes in the Ligurian Sea (NW Mediterranean, DYFAMED site) during 1995-2007 and biogeochemical consequences. Biogeosciences 7: $2117-2128$.

https://doi.org/10.5194/bg-7-2117-2010

Maynou F., Sabatés A., Salat J. 2014. Clues from the recent past to assess recruitment of Mediterranean small pelagic fishes under sea warming scenarios. Clim. Chang. 126: 175-188. https://doi.org/10.1007/s10584-014-1194-0

MEDOC Group. 1970. Observation of formation of deep water in the Mediterranean Sea, 1969. Nature 227: 1037-1040. https://doi.org/10.1038/2271037a0

Millot C. 1990. The Gulf of Lions' hydrodynamics. Cont. Shelf Res. 10: $885-894$ https://doi.org/10.1016/0278-4343(90)90065-T

Millot C. 2013. Levantine Intermediate Water characteristics: An astounding general misunderstanding. Sci. Mar. 77: 217-232. https://doi.org/10.3989/scimar.03518.13A

Navarro-Martín L., Viñas J., Ribas L., et al. 2011. DNA Methylation of the Gonadal Aromatase (cyp19a) Promoter Is Involved in Temperature-Dependent Sex Ratio Shifts in the European Sea Bass. PLoS Genet. 7: e1002447. https://doi.org/10.1371/journal.pgen.1002447

Nunes S., Latasa M., Gasol J.M., et al. 2018. Seasonal and interannual variability of phytoplankton community structure in a Mediterranean coastal site. Mar. Ecol. Prog. Ser. 592: 57-75. https://doi.org/10.3354/meps12493

Ojeda E.. Guillén J. 2008. Shoreline dynamics and beach rotation of artificial embayed beaches. Mar. Geol. 253: 51-62. https://doi.org/10.1016/j.margeo.2008.03.010

Orejas C., Gori A., Lo Iacono C., et al. 2009. Cold-water corals in the Cap de Creus canyon, north-western Mediterranean: spatial distribution, density and anthropogenic impact. Mar. Ecol. Prog. Ser. 397: 37-51. https://doi.org/10.3354/meps08314

Palanques A., Puig P., Durrieu de Madron X., et al. 2012. Sediment transport to the deep canyons and open-slope of the western Gulf of Lions during the 2006 intense cascading and open-sea convection period. Prog. Oceanogr. 106: 1-15. https://doi.org/10.1016/j.pocean.2012.05.002

Puig P., Palanques A., Orange D.L., et al. 2008. Dense shelf water cascades and sedimentary furrow formation in the Cap de Creus Canyon, northwestern Mediterranean Sea. Cont. Shelf Res. 28: 2017-2030. https://doi.org/10.1016/i.csr.2008.05.002

Puig P., Durrieu de Madron X., Salat J., et al. 2013. Thick bottom nepheloid layers in the western Mediterranean generated by deep dense shelf water cascading. Prog. Oceanogr. 111: 1-23. https://doi.org/10.1016/i.pocean.2012.10.003

Rholing E.J., Bryden H. 1992. Man-induced salinity and temperature increases in western Mediterranean deep water. J. Geophys. Res. 97: 11191-11198. https://doi.org/10.1029/92JC00767

Ribó M., Puig P., Palanques A., et al. 2011. Dense shelf water cascades in the Cap de Creus and Palamós submarine canyons during winters 2007 and 2008. Mar. Geol. 284: 175-188. https://doi.org/10.1016/j.margeo.2011.04.001

Romero E., Peters F., Arin L., et al. 2014. Decreased seasonality and high variability of coastal plankton dynamics in an urban location of the NW Mediterranean. J. Sea Res. 88: 130-143. https://doi.org/10.1016/j.seares.2014.01.010

Salat J., Font J. 1987. Water mass structure near and offshore the Catalan coast during the winter of 1982 and 1983. Ann. Geophys. 5: 49-54.

Salat J., Pascual J. 2002. The oceanographic and meteorological station at l'Estartit (NW Mediterranean). In: Briand F. (ed.). Tracking long-term hydrological change in the Mediterranean Sea. CIESM Workshop Series 16: 29-32. Monaco.

Salat J., Pascual J. 2006. Principales tendencias climatológicas en el Mediterráneo Noroccidental, a partir de más de 30 años de observaciones oceanográficas y meteorológicas en la costa catalana. In: Cuadrat Prats J.M., Saz Sánchez M.A., Vicente Serrano S.M., et al. (eds) Clima, sociedad y medio ambiente. Publicaciones de la Sociedad Española de Climatología, Zaragoza.

Salat J., García M., Cruzado A., et al. 2002. Seasonal changes of water mass structure and shelf slope exchanges at the Ebro shelf (NW Mediterranean). Cont. Shelf Res. 22: 327-346. https://doi.org/10.1016/S0278-4343(01)00031-0

Salat J., Emelianov M., Lopez-Jurado J.L. 2006. Unusual extension of 
Western Mediterranean deep water formation during winter 2005. In: Proceedings $5^{\text {a }}$ Asamblea Hispano-Portuguesa de Geodesia y Geofísica [CD-ROM]. Universidad de Sevilla, Sevilla, Spain.

Salat J., Emelianov M., Puig P. 2009. From Bottom Water (Lacombe, 1985) to New-WMDW since 2005. Possible shifts on Open Sea Deep Convection. CIESM Workshop Monographs 38: 41-49.

Sampedro N., Reñé A., Vila M., et al. 2008. Final Report 20042007: Pla de vigilància de fitoplàncton nociu i tòxic a la costa catalana. (Convenio CV03000044,Agència Catalana de l'Aigua (ACA). Generalitat de Catalunya i Institut de Ciències del Mar (ICM), CMIMA-CSIC).

Schlegel R.W., Oliver E.C.J., Wernberg T., et al. 2017. Nearshore and offshore co-occurrence of marine heatwaves. Prog. Oceanogr. 151: 189-205. https://doi.org/10.1016/j.pocean.2017.01.004

Schroeder K., Ribotti A., Borghini M., et al. 2008. An extensive Western Mediterranean deep water renewal between 2004 and 2006. Geophys. Res. Lett. 35: L18605. https://doi.org/10.1029/2008GL035146

Schroeder K., Millot C., Bengara L., et al. 2013. Long-term monitoring programme of the hydrological variability in the Mediterranean Sea: a first overview of the HYDROCHANGES network. Ocean Sci. 9: 301-324. https://doi.org/10.5194/os-9-301-2013

Siokou-Frangou I., Christaki U., Mazzocchi M.G., et al. 2010. Plankton in the open Mediterranean Sea: a review. Biogeosciences 7: 1543-1586. https://doi.org/10.5194/bg-7-1543-2010

Somot S., Houpert L., Sevault F., et al. 2016. Characterizing, modelling and understanding the climate variability of the deep water formation in the North-Western Mediterranean Sea. Clim. Dyn. 51: $1179-1210$. https://doi.org/10.1007/s00382-016-3295-0

Taviani M., Angeletti L., Beuck L., et al. 2016. On and off the beaten track: Megafaunal sessile life and Adriatic cascading processes. Mar. Geol. 375: 146-160.

https://doi.org/10.1016/j.margeo.2015.10.003

Tel E., Balbin R., Cabanas J.-M., et al. 2016. IEOOS: the Spanish Institute of Oceanography Observing System, Ocean Sci. 12: 345-353. https://doi.org/10.5194/os-12-345-2016

Tsimplis M.N., Baker T.F. 2000. Sea level drop in the Mediterranean Sea: An indicator of deep water salinity and temperature changes. Geophys. Res. Lett. 27: 1731-1734. https://doi.org/10.1029/1999GL007004

Ulses C., Estournel C., Puig P., et al. 2008. Dense water cascading in the northwestern Mediterranean during the cold winter 2005. Quantification of the export through the Gulf of Lion and the Catalan margin. Geophys. Res. Lett. 35: L07610.

Vargas-Yáñez M., Salat J., Luz Fernández de Puelles M., et al. 2005. Trends and time variability in the northern continental shelf of the western Mediterranean. J. Geophys. Res. 110: C10019.

Vargas-Yáñez M., García M.J.., Salat J., et al. 2008. Warming trends and decadal variability in the Western Mediterranean shelf. Global Planet Chang. 63: 177-184. https://doi.org/10.1016/j.gloplacha.2007.09.001

Vargas-Yáñez M., Moya F., García-Martínez M.C., et al. 2010. Climate change in the Western Mediterranean Sea 1900-2008. J. Mar. Syst. 82: 171-176. https://doi.org/10.1016/j.jmarsys.2010.04.013

Yentsch C.S., Menzel D.W. 1963. A method for the determination of phytoplankton chlorophyll and pheophytin by fluorescence. Deep-Sea Res. 10: 221-231. 